\title{
Child Care Subsidies and the Stability and Quality of Child Care Arrangements
}

\author{
Caroline Krafft ${ }^{\mathrm{a}}$, Elizabeth E. Davis ${ }^{\mathrm{b}}$, and Kathryn Tout ${ }^{\mathrm{c}}$
}

\author{
${ }^{a}$ St. Catherine University \\ Department of Economics \\ 2004 Randolph Ave. \\ St. Paul, MN, 55105 \\ United States \\ Phone: +1 651 690-6679 \\ E-mail: cgkrafft@stkate.edu \\ Corresponding author \\ ${ }^{\mathrm{b}}$ University of Minnesota \\ Department of Applied Economics \\ 1994 Buford Avenue \\ St. Paul, MN 55108-6040 \\ United States \\ Phone: +1 612-625-3772 \\ E-mail: edavis@umn.edu \\ ${ }^{\mathrm{c}}$ Child Trends \\ 708 North First St. Suite 333 \\ Minneapolis, MN 55401 \\ United States \\ Phone: +1 612 331-2223 \\ E-mail: ktout@childtrends.org
}




\section{Acknowledgements}

The authors gratefully acknowledge funding for this study provided through the Office of Planning, Research and Evaluation in the Administration for Children and Families, US Department of Health and Human Services (grant numbers 90YE098 and 90YE0132). The contents of this paper are solely the responsibility of the authors and do not necessarily represent the official views of the Office of Planning, Research and Evaluation, the Administration for Children and Families, or the US Department of Health and Human Services. Davis also acknowledges the support of the USDA National Institute of Food and Agriculture, Hatch Multistate Project NE-1049 and Minnesota Agricultural Experiment Station Project MIN-14-081. We thank Child Trends researchers for project support and participants in the University of Minnesota Department of Applied Economics Labor Workshop and at the APPAM 2014 conference for their helpful questions, comments and suggestions.

\footnotetext{
Abstract

Each month, the child care subsidy program helps nearly a million low-income families pay for child care. The financial support of a child care subsidy might be expected to increase stability and quality of care, which are characteristics of care that support child development. However, there are concerns that short durations of subsidy receipt may increase child care instability. Further, there is debate about whether subsidy receipt leads to the use of higher or lower quality care. In this study we use longitudinal survey data on low-income families and linked administrative data on subsidy receipt to investigate the stability and reported quality of child care arrangements. Because we observe the same children repeatedly over time, both when they
} 
are and are not receiving child care subsidies, we use child fixed-effects models to address the selection problems that otherwise would bias the relationships among subsidy, stability, and quality. We find that when children received child care subsidies they experienced higher quality care as reported by parents. Yet there was no difference in the stability of care arrangements while receiving subsidy compared to when not receiving subsidy. Additionally, children often had multiple providers concurrently, regardless of subsidy receipt. These results suggest that child care subsidy receipt may promote positive child outcomes due to increased access to higher quality care without worsening the stability of care.

Keywords: child care; child care subsidy; child care instability; child care quality; child development; low-income families 


\section{Introduction}

Through the Child Care and Development Fund (CCDF), child care subsidy programs support dual goals of encouraging parental employment and improving the quality of care for all children (Office of Child Care, 2015). With combined state and federal spending of \$11.4 billion, 1.5 million children were served monthly in federal fiscal year 2012 (Matthews \& Schmit, 2014). A key element of the program is to increase access to care while promoting parental choice of care that best meets the family's needs (Administration for Children and Families Department of Health and Human Services, 2014). Children receiving child care subsidies typically do so through a voucher that helps cover the cost of child care with an eligible provider who is selected by the family. The Child Care and Development Block Grant Act of 2014, which reauthorized CCDF for the first time since 1996, added program goals to "reinforce parental and family choice in determining the best setting for children while also placing a renewed focus on the quality of care" (U.S. Senate Committee on Health Education Labor and Pensions, 2014, p. 5). The 2014 legislation also made a number of changes intended to increase the stability of care arrangements. Whether the child care subsidy program improves access to stable, high quality care is a question of substantial importance to policymakers. Thus, this paper, which investigates the relationships between subsidy receipt and the perceived quality and stability of children's care, is particularly timely and relevant.

\section{Conceptual Model}

Families make decisions about child care arrangements within a complex landscape of constraints, options, social norms and inter-related decisions (Chaudry, Henly, \& Meyers, 2010; Meyers \& Jordan, 2006). Parents' use of a particular child care arrangement has been described as an "accommodation" rather than a choice, balancing family needs and resources within a 
specific social and geographic context (Meyers \& Jordan, 2006). Parents' decisions about which non-parental care arrangement(s) to use (if any) and if or when to change care underlie the stability and quality outcomes we examine in this study.

The preferences-and-constraints model of family decision-making (Casper \& Smith, 2004) assumes that parents select the care arrangement that best meets the family's needs given the time and budget constraints faced by the household, as well as their preferences and priorities (Becker, 1981; Connelly, 1992). Receiving a subsidy to help pay for child care may influence the type, frequency, quality and stability of child care arrangements used by a family. The financial support of a subsidy is expected to increase the set of options available to families (Adams \& Rohacek, 2002), for instance making center care more affordable. Receiving a subsidy may allow families to use higher quality care or a more preferred care setting because subsidies increase the resources available to families, lessening their budget constraints. These subsidized arrangements may also be more stable, as parents using their preferred type of care are less likely to change child care arrangements (Gordon \& Hognas, 2006). More resources may allow parents to use more, or fewer arrangements to accommodate work schedules as well as to meet child needs (Morrissey, 2008).

However, even with a subsidy it may be the case that care alternatives are not available to parents, still not affordable to parents, or not preferred by parents (Chaudry, 2004; Chaudry et al., 2011; Meyers \& Jordan, 2006). For example, there may be no centers available or affordable locally, even with a subsidy, or families may prefer home-based care for an infant regardless of subsidy receipt. While receiving a subsidy may allow parents to choose higher quality care arrangements, parents must "prioritize" quality and be able to identify and locate higher quality care, which may not be available locally (Ryan, Johnson, Rigby, \& Brooks-Gunn, 2011). Parents 
may prefer a free public program such as Head Start or public pre-kindergarten for children who are eligible, if slots are available. Therefore, in some (but not all) cases, we expect that parents will use different child care arrangements when they receive child care subsidies than when they do not. If parents choose different care arrangements when receiving subsidies, these arrangements can potentially affect a host of outcomes. The characteristics of these different care arrangements may then affect child development outcomes (Belsky et al., 2007; Claessens \& Chen, 2013; Dearing, McCartney, \& Taylor, 2009; de Schipper, Van Ijzendoorn, \& Tavecchio, 2004; Howes \& Hamilton, 1992; McCartney, Dearing, Taylor, \& Bub, 2007; Pilarz \& Hill, 2014; Tran \& Weinraub, 2006). Thus, one potential pathway for subsidies to influence child development is by changing the child care arrangement choices parents make when receiving child care subsidies.

\section{The Present Study}

This paper exploits unique longitudinal survey data on low-income families in Minnesota linked with administrative data from the state child care subsidy program to investigate the relationship between receipt of child care subsidies and the stability and perceived quality of children's care. Because we have longitudinal data on receipt of subsidy and child care arrangements, we are able to use a different approach from previous studies to account for selection bias. We estimate child fixed effects models to compare child care outcomes for the same child over time and examine, when the child receives subsidy, whether stability and perceived quality are different than when the same child does not receive subsidy.

Fundamentally we are studying the changes in outcomes when the child is in subsidized care compared to when she is not, using the child as her own control group. Our specific research questions are: 
1) How does subsidy receipt alter the stability of child care arrangements?

2) Is subsidy receipt related to the number of concurrent child care arrangements for a particular child?

3) How does the perceived quality of care children experience differ depending on subsidy receipt?

In investigating these research questions, we also explore mechanisms that might explain the impact of subsidy, by examining parents' reasons for selecting different arrangements.

\section{Previous Empirical Evidence on Child Care Subsidies and Child Care Arrangements Child Care Subsidies and Child Care Stability}

Parents may change their child care arrangements for a variety of reasons, including dissatisfaction with the care, the arrangement closing, no longer being affordable, alternatives becoming available (including higher-quality alternatives), or changes in children's developmental needs. While some changes may support child development, instability in child care, which is often measured as the frequency or probability of changing child care arrangements, can have negative effects on the emotional, behavioral, and cognitive development of children (Adams \& Rohacek, 2010; de Schipper et al., 2004; Loeb, Fuller, Kagan, \& Carrol, 2004; Pilarz \& Hill, 2014; Sandstrom \& Huerta, 2013; Tran \& Weinraub, 2006). Whether subsidies alter child care stability therefore is a question with important implications for child development.

One reason for the concern that receipt of child care subsidies may increase child care instability is the short durations of subsidized care ("spells") children experience. Nationally, the 
median length of subsidy spells is around six months (Swenson, 2014). There is, however, substantial state-by-state variation with median state durations that range from 13 months (District of Columbia) to as short as 3 months (Nevada) (Swenson, 2014). The median length of subsidy spells in a previous study in Minnesota was eight months (Davis, Krafft, \& Tout, 2014). Policies that require recertification of eligibility or other paperwork requirements may disrupt subsidy and contribute to child care instability (Davis, Krafft, \& Forry, 2016; Grobe, Weber, \& Davis, 2008). Short durations of subsidy receipt may include even shorter durations of subsidized care with a particular care provider (Henly et al., 2015; Weber, 2005). However, children may continue with the same provider when not receiving subsidy. In Wisconsin, $37 \%$ of children who exited and then returned to the subsidy program did so with the same provider (Ha, Magnuson, \& Ybarra, 2012) and in Minnesota, half did so (Davis, Krafft, et al., 2014), suggesting that some children likely continued with the same provider even when not subsidized. While previous studies have shown that children receiving subsidies experience unstable care arrangements, children from low-income families in general also have substantial volatility in their child care arrangements (Adams \& Rohacek, 2010; Chaudry, 2004; Lowe, Weisner, Geis, \& Huston, 2005; Pilarz \& Hill, 2014; Tran \& Weinraub, 2006). For instance, more than half of children from low-income families changed their primary child care provider over a period of six months in both Minnesota and Maryland (Krafft, Davis, \& Tout, 2014; Krafft, Davis, Tout, \& Forry, 2013). Thus, there is not clear evidence whether child care subsidy recipients have more or less instability than other low-income families. Although one study of child care changes in Minnesota demonstrated that respondent-reported receipt of subsidy was not related to the probability of subsequent changes in primary provider (Davis, Carlin, \& Krafft, 2014), that study was not able to correct for selection into the subsidy program. 
Results from one randomized treatment-control study provide some causal evidence of the impact of subsidy receipt on child care stability. Families in Cook County, Illinois were randomly assigned to either receive or not receive a child care subsidy, and the study followed their patterns of care over time (Michalopoulos, Lundquist, \& Castells, 2010). The authors concluded that child care subsidies increased care stability, since $92 \%$ of children who received subsidies never experienced an interruption in their primary care arrangement, compared to $89 \%$ of children who did not receive subsidies. While the study was based on a strong research design, the findings were based on child care histories that suffered from recall issues. For instance, the study surveyed families on their care arrangements one to two years after randomization. When asked retrospectively about child care at the time of random assignment, only $52 \%$ of subsidy recipients reported using non-parental care at that time, although to receive subsidy, all these families had to have been using non-parental care (Michalopoulos et al., 2010). In addition, the study included only individuals between $50 \%$ and $65 \%$ of the state median income, who were not likely to be representative of the low-income population typically eligible for subsidies. Thus, there is a need for additional research on how subsidy affects stability of care among low-income families.

\section{Child Care Subsidies and Use of Multiple Concurrent Care Arrangements}

While there exists debate on whether having multiple child care arrangements can itself be considered a form of child care instability (Adams \& Rohacek, 2010), in this paper we distinguish between the concept of multiple concurrent care arrangements (multiplicity) and instability, that is whether a particular arrangement continues or ends. Research shows that multiple (concurrent) child care arrangements are common yet can have negative impacts on children's development (Claessens \& Chen, 2013; de Schipper et al., 2004; Morrissey, 2009; 
Pilarz \& Hill, 2014; Tran \& Weinraub, 2006). Among infants, just half used only one arrangement at a time, and multiple arrangements included both temporary and longer-term situations (Tran \& Weinraub, 2006). Parents use multiple arrangements for a variety of reasons, such as providing their children with a variety of early environments (e.g., both relative care and formal care promoting school readiness) or to cover the time parents spend in work or in school (Morrissey, 2008). Qualitative work on families transitioning from welfare to work highlights the role of multiple arrangements acting as a "patchwork" of care for children (Scott, London, \& Hurst, 2005). Multiple arrangements may often be a necessity rather than a matter of preference.

Few studies have examined the relationship between subsidy receipt and use of concurrent multiple providers. One approach is to compare the number of providers children have (Morrissey, 2008, 2009; Pilarz, Claessens, \& Gelatt, 2016; Tran \& Weinraub, 2006) to the number of subsidized providers children have (Davis, Krafft, et al., 2014; Weber, 2005). Such comparisons demonstrate that the average number of providers for children overall tends to be greater than the number of subsidized providers for a child receiving subsidy. This result indicates that either receiving a subsidy allows parents to use fewer providers or that even when using subsidies, parents may require additional unsubsidized providers to cover their children's care needs. The Cook County study found subsidized children were less likely to have multiple providers (by three percentage points) (Michalopoulos et al., 2010), but as with the study's other results, recall and generalizability are problematic. In Minnesota, children averaged 1.06 subsidized providers per month and $25 \%$ of children experienced multiple providers within a spell of subsidy receipt. Most of the months with multiple providers were likely transitions from one provider to another (Davis, Krafft, et al., 2014). If families can meet all of a child's care needs with a single provider when receiving a subsidy, the decrease in multiplicity of 
arrangements may be a mechanism for positive impacts on children's development. It may also be the case that families use a mix of both subsidized and unsubsidized arrangements, such that multiplicity is no different as a result of receiving subsidy. However, there is little direct evidence to date on this question.

\section{Child Care Subsidy and Child Care Quality}

The quality of care children experience has important implications for their short and long term development, particularly for children in low-income families (Belsky et al., 2007; Dearing et al., 2009; McCartney et al., 2007; Tran \& Weinraub, 2006). Because child care subsidies lessen income constraints for families, parents may have a larger set of feasible choices and may be able to select more expensive, higher-quality child care (Adams \& Rohacek, 2002). However, the evidence to date on whether subsidy receipt results in higher quality care has been mixed. A number of studies have found that those who receive child care subsidies are more likely to use center care (Burstein \& Layzer, 2007; Crosby, Gennetian, \& Huston, 2005; Ertas \& Shields, 2012; Herbst, 2008; Marshall, Robeson, Tracy, Frye, \& Roberts, 2013; Tekin, 2005; Weber, Grobe, \& Davis, 2014; Weinraub, Shlay, Harmon, \& Tran, 2005; Wolfe \& Scrivner, 2004). Center care is documented to be higher quality on average than other types of care on some indicators of quality (Bassok, Fitzpatrick, Greenberg, \& Loeb, 2016; Bigras et al., 2010; Dowsett, Huston, Imes, \& Gennetian, 2008; Fuller, Kagan, Loeb, \& Chang, 2004) and can support developmental gains (Campbell, Ramey, Pugnello, Sparling, \& Miller-Johnson, 2002; Loeb et al., 2004; NICHD Early Child Care Research Network, 2002; Reynolds \& Temple, 1998; Schweinhart \& Weikart, 1998).

While consistent evidence is found linking increased use of center-based care and subsidies, direct evidence on the relationship between subsidy receipt and quality of care is 
mixed. Studies that compare providers who accept subsidies to those that do not generally report the former to be lower quality (Jones-Branch, Torquati, Raikes, \& Edwards, 2004; Raikes et al., 2013). Weinraub and colleagues (2005) found no relationship between subsidy and quality of care when focusing on a low-income sample. Several studies have linked child care subsidies with poorer developmental outcomes among subsidized children (Hawkinson, Griffen, Dong, \& Maynard, 2013; Herbst \& Tekin, 2010). The studies speculate, but do not demonstrate, that these poorer developmental outcomes may be due to low quality child care. Herbst and Tekin (2010) used instrumental variables methods and found that child care subsidies negatively impact child development, which they conjectured was because subsidized children were in lower quality care. However, Hawkinson, et al. (2013) note that their similar finding, that subsidy receipt had a negative association with child development outcomes, could be due to selection into the program.

In contrast, several recent studies find a positive association between child care subsidies and child care quality after correcting for selection on observable characteristics by using propensity score matching (Johnson, Ryan, \& Brooks-Gunn, 2012; Ryan et al., 2011). Two studies also find higher quality care used by those on subsidies compared to families on the waiting list (Berger \& Black, 1992; Marshall et al., 2013). Thus the recent evidence using quasiexperimental methods provides evidence that subsidy receipt results in use of higher quality care. The relationship between subsidy use and quality of care is likely to be more nuanced, however, and may vary with the type of care used. Ryan and colleagues (2011) concluded that while overall, quality was higher for those using subsidies, the result was due to the increased use of center-based care. Within care types, those using family child care while receiving subsidy used higher quality care, and those using centers used lower quality care, compared to families not 
receiving subsidies. Further, Johnson et al. (2012) found that subsidy recipients experienced lower quality care than nonrecipients who accessed free public programs such as Head Start or public pre-kindergarten programs.

\section{Challenges in Identifying the Impact of Subsidy Receipt on Child Care Outcomes}

In addition to selecting child care arrangements, parents also make decisions with regard to applying for and taking up child care subsidies, if they are eligible. A major challenge in estimating the impact of child care subsidies on the stability and quality of care is that families who (choose to) receive subsidies may be different from families not receiving subsidies in ways that bias the observed relationships between subsidy, stability, and quality. For instance, the duration of child care arrangements may be short among low-income families regardless of subsidy status. So a relationship between subsidy receipt and instability of care could be driven by the fact that subsidy recipients have low incomes, and low-income families have less stable care. Or it may be that only families who value certain types of child care seek child care subsidies (Burstein \& Layzer, 2007; Johnson, Martin, \& Brooks-Gunn, 2011). If these care settings are of higher quality, then subsidy recipients would tend to be in higher quality caredue to parental preferences for that type of care.

Information that can be used to control for selection into the subsidy program is not readily available. In addition, to assess instability of care, longitudinal data are needed. Accurate data on both child care arrangements and subsidy receipt over time are needed for such studies. Self-reported or retrospective survey data are likely to suffer from substantial biases which could generate erroneous estimates (Krafft, Davis, \& Tout, 2015; Michalopoulos et al., 2010).

This study investigates the relationship between child care subsidy receipt, child care stability, multiplicity of arrangements, and the perceived quality of care. The analysis also 
investigates mechanisms, such as type of care or reasons for having multiple providers, which might explain these relationships. Two of the key advantages of our current study are that we have longitudinal data (not retrospective data) on child care arrangements and in addition, we link the longitudinal survey data with administrative data to identify subsidy receipt. The use of administrative data is particularly important for accurately identifying the impacts of the subsidy program, as other studies have shown potential problems in measuring subsidy receipt in survey data (Johnson \& Herbst, 2013; Krafft et al., 2015). Estimated program impacts will be biased if survey responses about subsidy receipt are inaccurate (Krafft et al., 2015). The current study contributes to the existing evidence with new methods and data that can help identify the impact of subsidy receipt on child care outcomes.

\section{Methods}

\section{Data}

\section{Survey Data.}

Parents in Minnesota were recruited to participate in a longitudinal study examining child care arrangements, stability, perceptions of quality and use of financial assistance for child care. The parent survey recruited families with at least one child aged six or younger who had applied to receive financial assistance through Minnesota's cash assistance programs (welfare or child care assistance). The sample was limited to families living in one of seven counties. Potential survey respondents were given packets of information about the study at the county social services office and asked if they would participate. Of the 437 families who agreed to participate in the study, 323 (74\%) completed the baseline interview. The other families did not participate because 16 were not ultimately eligible, 24 later refused to participate when contacted, and 74 could not be reached by telephone. 
The telephone survey focused on the care arrangements for a randomly designated focal child under age six. The survey respondent was the person in the household with the most knowledge about the focal child's care arrangements, usually the mother. Extensive information was collected about the child care arrangements used for this child at each survey wave. Detailed information on parents' perceptions of elements of quality in the primary arrangement was gathered. The survey included rich information on child, family, and provider characteristics. Open-ended questions on issues such as why parents used multiple arrangements were also incorporated into the survey. Responses to these questions were examined to identify whether reasons were related to subsidy receipt. For more information about the survey design and sample, see Tout et al. (2011).

All five waves of the survey were used in this study, and there were an average of six months between waves. The surveys were completed between August 2009 and August 2012. The baseline sample included 323 families. Survey participation rates dropped over time, mostly due to difficulties in locating the families, and it was possible for families to be missing in one wave but to return in a later wave. There were 250 families in Wave 2, 218 families in Wave 3, 196 in Wave 4, and 146 in Wave 5. There were 133 families who completed all five waves. Because we use fixed effects models, as described below, our multivariate results are based on all families who responded to at least two survey waves, of which there are 259 . We do not impute missing data for waves when families who attrited. We present descriptive statistics for all children and families observed in the baseline survey. We also provide statistics by wave of the survey and then "pool" the data across waves. When pooling, an observation is a child in a particular wave; children will have the number of observations in the pooled sample equal to the number of waves in which they are observed. Thus there are a total of 1,133 observations in the 
pooled sample. Due to unique features of the outcomes we examine, some of which are changes over time, are restricted to a certain sub-group, or are limited to those with multiple waves of data, we do not have one single sample used for identification in our estimates. We describe the samples used for modeling with different methods in the estimation section, below, and present the characteristics of each analysis sample in the appendix.

\section{Administrative data on subsidy receipt and linking to survey data.}

The Minnesota Department of Human Services provided monthly administrative data on the families, children, and providers participating in the child care subsidy program through a data sharing agreement. With participant consent, survey responses were linked to the administrative records based primarily on respondent's name, gender and date of birth. Additional variables such as home address and child's date of birth and gender were confirmed as needed. Matching was done on a case-by-case basis and $98 \%$ of the survey respondents were found in the administrative database. The survey respondents were in the state database because of their application for and/or receipt of public benefits such as TANF, Medicaid or SNAP, regardless of whether they received child care subsidies. The linked administrative data were used only to identify whether children were receiving subsidy at the time of the survey and the number of subsidized providers they had. All other outcomes and covariates are from the survey data, in order to have this information for both subsidy recipients and non-recipients at each survey wave.

\section{Measures}

\section{Subsidy receipt.}

We define subsidy receipt in a given month using the administrative data based on whether the child utilized subsidized child care within that month. The administrative data 
include the month(s) for which a provider was paid for child care services for the focal child. We refer to these months as the child 'receiving' or 'utilizing' subsidized child care throughout the paper (based on when the care was received). However, in Minnesota the provider may be paid if the child is absent for a short period. Using the monthly administrative data, we determined whether each child was receiving subsidy in each wave of the survey based on the calendar month in which the survey was completed.

\section{Stability.}

We calculated two measures of the stability of child care arrangements: (i) whether the child changed primary provider between survey waves and (ii) whether the child changed any provider (as some children had more than one provider concurrently) between waves. Survey respondents were asked about all child care arrangements for the focal child that were used at least once a week for the two weeks prior to the survey wave, so a one-time use of a babysitter, for instance, would not be included. The primary provider was defined as the arrangement used most often. Respondents were asked directly whether the primary provider was the same individual (or program) as in the previous wave. Some studies consider another form of instability to be changes of caregiver or teacher within the same program. Our data do not provide sufficient detail to measure changes at the caregiver level in a center or other multicaregiver setting.

Children were defined as having a change in any provider if they changed primary provider or had stopped using a type of care or added a type of care between survey waves. Children who were in the same type of care but added or lost a provider within that care type also were defined as having a change in any provider. For children who had not changed type or number of providers, we compared the names of the providers for centers and out-of-home care. 
Names were not provided for in-home care, but the type of provider (relative, friend, neighbor, professional babysitter) and relationship (grandparent, sibling, aunt/uncle, other) were compared. We assumed that if the relationship was the same, the same individual continued. When comparing names, we allowed for interviewer mis-spellings over time (Sheryl and Cheryl, for instance) to be considered continuing with the same provider.

\section{Number of providers.}

In the survey, respondents were asked whether they used different types of care, including center, before/after school, summer, in home, and out of home care at least once a week within the past two weeks. We included before/after school care and summer care, which were infrequent, with center care. School (grades kindergarten and above) was not included in our count of child care arrangements. For both out of home and in home care, respondents were asked about the number of providers they used. Unfortunately, individuals using center care were not asked how many different centers they used. We add the number of providers of each type to obtain the total number of (non-parental) providers. While using multiple providers at least once a week within the past two weeks may sometimes represent a transition rather than having multiple providers on a regular basis, given the short time window of the questions and the high numbers of providers we find, below, transitions likely represent a small share of the observed multiple arrangements.

\section{Parents' perception of child care quality.}

There is an extensive literature on ways to conceptualize and measure quality of child care arrangements. This literature highlights both structural features (such as the child-teacher ratio and use of a curriculum) and process features reflecting the child's experience (such as warm, positive interactions between the caregiver and child and the provision of 
developmentally appropriate activities) as important elements of quality. Different measures and dimensions of quality are likely to be closely related. Thus, composite indices of quality combining structural and process features are common in the literature (Johnson et al., 2012;

Loeb et al., 2004; Marshall et al., 2013; Ryan et al., 2011). In the survey, we asked parents about their child's experience in the care setting including the parent's perception of structural features in the setting (for example, whether the teacher/caregiver uses a tool to track the child's development and whether the teacher/caregiver has formal training and education in the care of young children) and process features (for example, whether the teacher/caregiver provides individual attention and a variety of creative activities). The survey items were developed to mirror elements of quality included in Minnesota's quality rating and improvement system (QRIS) for early care and education programs. Accordingly, the wording of parent survey items matched promotional materials for the QRIS aimed at supporting parental understanding of the quality features that are important for children's school readiness (Tout et al., 2016). In addition, select items from a scale developed to measure parents' perception of quality were adapted for the survey (Emlen, Koren, \& Schultze, 2000). Parents' perceptions of quality tend to be higher than observer ratings of quality, but are correlated with direct observations of quality (Mocan, 2007). The inflation of quality ratings is less of a concern in the context of a fixed-effects model, where any fixed parental over-estimates of quality will be absorbed by the fixed effect. Essentially the model relates changes in perceived quality to changes in subsidy and other child and family characteristics. Further, as described below, parents were asked about specific actions and activities, from which we developed a quality measure, rather than asking parents for an overall quality or satisfaction rating. 
In each wave the parent responded to 17 different items about the primary provider framed within two survey questions listed in Table 1. Responses for both sets of questions were (1) Never (2) Rarely (3) Sometimes (4) Usually, or (5) Always. The questions and response options were the same regardless of the type of care used. In Waves 2 and 4, these questions were not asked of individuals who neither changed primary provider nor considered a change; since they are with the same provider as the previous wave (wave 1 or wave 3 ) we use experiences in the previous wave as the inputs for the quality factor. The full distribution of parent responses to these questions is presented in Table 1. The distribution tends to be skewed towards "always" responses, particularly for characteristics like whether the child likes the provider and whether there's a warm environment. However, there is a substantial degree of variation across respondents for the different questions.

Parent responses to the 17 quality items were reduced using factor analysis. The primary factor identified in the analysis, with an eigenvalue of 3.94, identified elements of high quality, with all variables entering positively with the exception of watching more than an hour of television. We refer to this factor as the quality factor. Factor loadings, uniqueness and scoring coefficients are presented in Table 1 . There are varying weights placed on the different indicators of quality, with creative activities, activities that fit the child's needs, learning new skills, use of a curriculum, availability of books, tracking of children's development using a formal tool, staff education, and diversity having particularly high weights. This pattern indicates an emphasis in the quality factor on more formal aspects of quality related to supports for children's school readiness. The factor is standardized to have a mean of zero and a standard deviation of one, so changes or differences in the quality factor can be interpreted in terms of standard deviations. 
Because the literature (Burstein \& Layzer, 2007; Crosby et al., 2005; Ertas \& Shields, 2012; Herbst, 2008; Tekin, 2005; Wolfe \& Scrivner, 2004) suggests that accessing different types of care may be one mechanism through which subsidy impacts quality, we undertake additional analyses to investigate whether type of care mediates perceived quality effects. We divide types of care into three categories: centers, family child care (FCC), and family/friend/neighbor (FFN) care, as is common in the literature. The latter two are distinguished based on their professionalization. Care in the child's home and care by relatives were classified as FFN. Otherwise, the parent was asked if the provider was a professional babysitter or nanny, if caregiving was the provider's primary job, and whether the provider cared for children not related to the respondent or the provider. If the parent answered yes to these questions, the provider was classified as FCC. Otherwise, the provider was considered FFN care. We do not distinguish based on licensing status, as parents are often unable to provide accurate information on whether a provider is licensed by the state.

\section{Estimation}

Selection into the subsidy program and unobserved differences between subsidy recipients and non-recipients are important potential threats to validity when estimating the impact of subsidy receipt on child and family outcomes (Burchinal \& Nelson, 2000). Families may choose to participate in the subsidy program due to unobservable characteristics that will bias results when estimating the impact of subsidy receipt, even with controls for observable factors related to selection. Our goal is to estimate the effect of subsidy receipt, $S$, for a child $i$ on outcome $Y$, controlling for child and family characteristics that might affect selection and outcomes, $X_{i}$. The estimated coefficient indicating the effect of subsidy receipt, $\gamma$, may be biased 
because of the relationship between factors we do not observe, which remain in the error term, $\varepsilon_{i}$, and the included covariates (see equation 1 ).

$$
Y_{i}=\beta_{0}+\gamma S_{i}+\beta X_{i}+\varepsilon_{i}
$$

However, these unobservables may be constant over time. So if we observe children at multiple points in time, we can estimate a model that includes a "fixed effect," $\alpha_{i}$, for each child, which does not vary over time. This fixed effect will capture families' unchanging unobservable differences, such as any time-invariant parental preferences for certain types of care, which may cause parents to both take up subsidy and select that type of care. While parental preferences may shift over time due to factors such as children aging, changing work, or new care options becoming available, these changes can be incorporated into the model. If there are any unobservable changes over time that affect both subsidy take up and outcomes, the model will still potentially be biased. However, if the model is correct, after including the fixed effect and observable factors that vary over time, $X_{i t}$, the estimated coefficient on the subsidy indicator, $\gamma$, can be interpreted causally as an unbiased estimate of the direct impact of subsidy receipt on the outcome $Y_{i t}$ (see equation 2) (Burchinal \& Nelson, 2000).

$$
Y_{i t}=\beta_{0}+\gamma S_{i t}+\beta X_{i t}+\alpha_{i}+\varepsilon_{i t}
$$

This approach to addressing selection is sometimes referred to as a "within" model, as in a within-child (and over time) comparison. Because of its substantial data requirements (multiple time points for the same child) it is not frequently used in examining child outcomes. When feasible, the fixed effects model has the advantage of controlling for fixed unobservable factors, over methods that rely on observable variables only for controls or matching. However, if there remain time-varying unobserved factors driving families' decision making, only some biases will be removed by this method while others will persist. Fixed effects methods have been used in 
assessing the impact of child care choices in other settings, for instance in examining the relationship between multiple child care arrangements and children's behavior (Morrissey, 2009) or the effect of income on child development (Blau, 1999). The main downside of using fixed effect methods is likely to be reduction in the power to test hypotheses and larger standard errors (Burchinal \& Nelson, 2000). Fortunately, in our results below, we have sufficiently precise estimates to test our hypotheses of interest about the impacts of subsidy receipt.

Fixed effects models were estimated for each of three different outcome measures: 1) a binary variable for change in primary provider between survey waves; 2) number of concurrent arrangements (multiplicity); and 3) perceived quality, as quantified by the factor analysis described above. We estimated fixed effects ordinary least squares (OLS) models for the quality factor and for the number of providers, and all children observed in at least two survey waves were included in the analysis. The results for number of providers were not substantively different when a fixed effects count (Poisson) model was estimated instead of OLS.

The model for child care stability is slightly more complex, as stability is measured as a change in provider between survey waves. The outcome of interest is the probability of a change in primary provider for child $i$ between time $t$ (referred to as the initial survey wave) and time $t+l$ (the subsequent wave). In equation 3 this outcome is denoted as $\Delta P_{i t+l}$. Note that the initial wave is not the same as the baseline of the survey; the initial wave could be wave 4 and the subsequent wave would be wave 5. A number of characteristics, $X_{i t}$, as measured in initial time $t$, may affect the likelihood of changing child care, such as whether there are other children in the family. Subsidy receipt, $S_{i t}$, is also measured in the initial period. In this case, $\gamma$ is an estimate of the impact of having subsidy at one point in time on the probability of subsequently changing 
care. Changes in the family's circumstances between time $t$ and $t+1$ may also affect whether the child changes care. We denote these changes, such as the birth of a new child, as $\Delta Z_{i t+1}$.

$$
\operatorname{Probability}\left(\Delta P_{i t+1}\right)=\beta_{0}+\gamma S_{i t}+\beta X_{i t}+\delta \Delta Z_{i t+1}+\alpha_{i}+\varepsilon_{i t}
$$

For the model of child care stability, the sample includes all children observed with at least two potential changes - so children observed in at least three survey waves. Because five waves is the maximum observed, the maximum number of potential changes observed for a child is four. To estimate models for the probability of changing primary provider, we use a fixed effects linear probability model, which applies ordinary least squares (OLS) to the binary outcome. Our findings were not substantively different when a conditional logit fixed effects model was used instead.

One of the disadvantages of the fixed effects model is that it can only estimate coefficients for characteristics that vary over time. Anything that is inherently constant (such as ethnicity or race) is necessarily absorbed into the fixed effects. This is a major disadvantage if one wants to estimate the impact of constant characteristics on an outcome. However, since our goal is to test the impact of subsidy receipt (which does change over time) on various outcomes, having the effects of characteristics that do not vary over time absorbed into the fixed effects is not a problem; it should just be kept in mind that additional constant characteristics (such as child gender), are effectively included within the child fixed effects (and therefore do not have a separate estimated parameter). A related model to the fixed effects model is the "random effects" model, which has the advantage of allowing for the estimation of all coefficients. However, it essentially assumes that the differences ("effects") for each child are randomly distributed and in no way related to the observed covariates, an unlikely assumption in this case. 


\section{Covariates}

In each of the fixed effects models, we control for a number of time-varying child and family characteristics noted in the literature to be related to parents' child care decisions (Chaudry et al., 2011). These factors include the composition of the household, namely whether the parent is single, the number of other adults in the household, the number of children under age 6 , and the number of children age 6 to 12 years (Tang, Coley, \& Votruba-Drzal, 2012). The age of the focal child (categorized as infant, toddler, preschool age, and school age), is also expected to influence child care decisions (Coley, Votruba-Drzal, Collins, \& Miller, 2014). Family economic circumstances are likely to influence child care decisions by affecting resource constraints and need for care (Burstein \& Layzer, 2007; Chaudry et al., 2011; Tang et al., 2012). We include whether the parent is employed full-time, part-time or not employed. We also incorporate measures of whether the parent is engaged in education or training activities, along with a categorical income variable and a welfare receipt variable. Another important constraint on care choices that we include in our models is whether a family member or friend is available to care for the child regularly (Davis, Carlin, et al., 2014; Davis \& Connelly, 2005). For the models of the multiplicity and perceived quality outcomes, these covariates were measured contemporaneously, that is, in the same survey wave as the outcome variable. For the model of the probability of changing providers, these covariates were measured in the initial wave. Additional variables in the stability models include measures of whether the family moved or had a new baby between the survey waves. These changes in family circumstances were expected to increase the likelihood of changing providers (Davis, Carlin, et al., 2014). 


\section{Sample Descriptives}

Table 2 provides basic descriptive statistics of the sample at baseline $(\mathrm{N}=323)$ and pooled over waves $(\mathrm{N}=1,133)$ in order to provide a comparison of the families in this study with the full sample (before attrition). In the appendix we present the sample characteristics at each wave for each of our analysis samples, which vary across outcomes and methods. At baseline, the 323 children in the sample were primarily in FFN care (45\%), followed by center care (31\%), parental care only (12\%) and FCC care (12\%). Children were almost evenly split by gender ( $51 \%$ female). By design the children were under age six, and at baseline, $31 \%$ were infants (under 16 months), 28\% toddlers (17-32 months) and 36\% were preschool aged (33 months and above, not yet in school). A small percentage (5\%) were school-aged by the time of the first interview. The majority of children were non-white, non-Hispanic (58\%), while $29 \%$ were white and $13 \%$ Hispanic. Nearly two-thirds (64\%) of children lived in single parent households. Close to $40 \%$ of the parents responding to the baseline survey had at least some college education while a quarter (26\%) had not completed high school. Nearly $60 \%$ were not employed at the time of the baseline survey and $71 \%$ reported receiving welfare (TANF).

The pooled data demonstrate that, despite attrition, the characteristics of the pooled sample are similar to the baseline sample. Specifically, there is little variation between time-invariant characteristics such as child sex, child race, and respondent education between the baseline and pooled samples. For instance, while $29 \%$ of the baseline sample is White, non-Hispanic, $30 \%$ of the pooled sample is White, non-Hispanic. The share Hispanic shifts from $13 \%$ to $11 \%$ and the share non-white, non-Hispanic from 58\% to 59\%. We would expect a number of other characteristics to naturally change over time, such as incomes shifting since we targeted a lowincome sample initially and would expect some families to move to higher income brackets. 
However, patterns remain similar here as well across the baseline and pooled samples, with 53\% of families having household income below $\$ 15,000$ in the baseline and 50\% in the pooled sample. By far the largest differences between the baseline and pooled samples are children's ages, which is natural as children age across waves, as well as some shifts into centers that are likely linked to child aging and development (Ansari \& Winsler, 2013; Morrissey, 2010).

In order to estimate the child fixed effects model, we need to observe the same children both when they are receiving and are not receiving subsidy. A sizeable share of children in the survey sample were receiving child care subsidies in each wave, based on the administrative data. Pooled across survey waves $(\mathrm{N}=1,133), 39 \%$ of children received subsidy on average. Looking at the survey waves individually, the percentage of children who received subsidy at the time of the survey in Wave $1(\mathrm{~N}=323)$ was $37.5 \%$, in Wave $2(\mathrm{~N}=250)$ was $39.6 \%$, in Wave $3(\mathrm{~N}=218)$ was 42.2\%, in Wave $4(\mathrm{~N}=196)$ was $38.8 \%$, and in Wave $5(\mathrm{~N}=146)$ was $33.6 \%$.

While the percentage of children receiving subsidies ranged only between $34 \%$ and $42 \%$ across the survey waves, this consistency masks a great deal of movement into and out of the subsidy program across the waves. Among the children who were present in all five survey waves, $17 \%$ received subsidies at the time of all five waves and $36 \%$ did so at none of the waves. The remaining $47 \%$ received subsidies at some but not all waves. Table 3 shows the percentage of children who exited subsidy and the percentage that began receiving subsidy between survey waves. Between $22 \%$ and $32 \%$ of children receiving subsidies at one wave then exited the subsidy program at some point over the approximately six months until the next wave, with an average of $26 \%$ in the pooled sample exiting subsidy. The average rate of entering the subsidy program was $16 \%$ in the pooled sample. From Wave 1 to Wave 2, 21\% of children not receiving subsidy in Wave 1 were receiving subsidy by Wave 2. Fewer children entered (or re-entered) the 
subsidy program in later survey waves, likely due to children's changing care needs and options as they got older. By Wave 4, none of the children in the longitudinal sample were infants (under 16 months) and only a quarter were toddlers (17-32 months); most were preschool or school aged and may have had different care needs or other options such as Head Start.

The instability of subsidy receipt observed in the survey sample is not surprising, given the relatively short spells of subsidy participation found in most states (Davis, Krafft, et al., 2014; Swenson, 2014). In Minnesota, an analysis of all children receiving subsidies estimated the median length of a subsidized arrangement to be six months, with a $25^{\text {th }}$ percentile of three months and a $75^{\text {th }}$ percentile of 12 months for a similar time period (Davis, Krafft, et al., 2014). Using the administrative data for the survey sample, we find that the survey sample had a similar pattern to all Minnesota subsidy recipients: a $25^{\text {th }}$ percentile of three months, a median of six months, and a $75^{\text {th }}$ percentile of 11 months for the length of time spent on subsidy and with a particular provider. The similarity between our sample of recipients and all recipients suggests our results are representative of subsidy recipients in Minnesota.

\section{Results}

For each of the outcomes of interest (stability, number of providers and quality of care) we present the results first in a simple descriptive framework comparing those receiving child care subsidies to those not receiving subsidies, and then present the results of the child fixed effects models.

\section{Patterns of Instability: Probability of Ending an Arrangement between Survey Waves}

Looking first at the results on child care instability patterns, Table 4 presents the percentage of children who changed primary provider and the percentage of children who had a change in any provider by initial subsidy status (measured at the first of two consecutive survey 
waves). Not only did half of children experience a change in their primary provider, but threequarters experienced at least one change in their care arrangements between the waves. Children who received subsidies in an initial wave were less likely to change primary provider by the subsequent wave than children who did not receive a subsidy. Children who moved from or to parent care only were included in the count of changes in primary provider (they started or ended a non-parental care arrangement). Previous research suggests that children in parental care only have a high chance of care changes between waves (Davis, Carlin, et al., 2014; Krafft et al., 2013). When those in parental care only were excluded (from the unsubsidized care group), rates were very similar to those presented for unsubsidized children overall. While 59\% of unsubsidized children in the pooled sample changed primary providers between waves, only $41 \%$ of subsidized children did so. There was less difference between subsidized and unsubsidized children in terms of the percentage who changed any provider. For both groups, about three-quarters experienced a change in any provider.

It is also possible for children to remain with the same provider when they stop receiving subsidies, or to have a previously unsubsidized provider who becomes subsidized. Given the relatively small sample size for individuals entering or exiting subsidy in each wave, we present only the pooled percentages of individuals across survey waves. Among those who exited subsidy between waves $(\mathrm{N}=83), 66 \%$ changed primary provider and $82 \%$ changed at least one provider. Compared to the rates for unsubsidized children, this rate of changing primary providers was around 7 percentage points higher and the rate of changing at least one provider was 5 percentage points higher. Families may change providers when they exit the subsidy program, or their circumstances may have changed in a way that required both exit from the subsidy program and a change in provider. 
Those entering the subsidy program also had high rates of changes in care. However, these changes may represent families switching to a preferred type of care. Among those who entered subsidy $(\mathrm{N}=74)$ between one wave and the next, $77 \%$ changed primary providers and $92 \%$ changed at least one provider. Table 5 suggests that the parents entering and exiting subsidy were often making more changes in their type of care (compared to those whose subsidy status did not change between waves). Those entering the subsidy program tended to move from less formal care, such as FFN care, to more formal care, such as centers (62\% of those initially in FFN care made a transition to centers). Those exiting the subsidy program moved to less formal care. Among those who were in centers when receiving subsidy, $37 \%$ moved to FFN care and $17 \%$ to parental care when they lost subsidy. Only 44\% remained in center care. Whether we looked at those receiving subsidies compared to those not, or at changes in care arrangements when entering or exiting subsidy, there were clearly different patterns of child care usage and slightly more stability of care when children were in subsidized care.

\section{Fixed Effects Model of Change in Primary Provider}

Although the patterns described above suggest that subsidy receipt is related to slightly higher rates of stability (fewer changes in primary provider), this result does not control for families' selection into the subsidy program. Therefore, we turn to the child fixed effects models to rigorously measure the impact of receiving a subsidy on the probability of changing primary provider (Table 6). Given that most children changed at least one of their providers between survey waves, we focus on stability of primary provider. The sample for this model was 217 children with 745 observations across waves. In the child fixed effects model, we find that stability was neither improved nor worsened by subsidy receipt; the estimated parameter for subsidy receipt was not a statistically significant predictor of changing primary provider. 
Additionally, the estimated change in probability was small, a decrease of just 1.6 percentage points in the probability of changing primary provider. We tested the sensitivity of our finding to removing observations where the child was initially in parental care only, since those who were in parental care had very high likelihood of changing care (i.e., starting to use non-parental care). The sample for this model was 196 children with 628 observations. The estimated coefficient on subsidy receipt increased in (absolute) size but remained statistically insignificant, suggesting that subsidy receipt reduced the probability of changing primary provider by 4.6 percentage points. From the results of the child fixed effects model, overall we conclude that stability of care was neither increased nor decreased when families received child care subsidies.

While instability was not related to subsidy receipt, overall there was a high level of instability of child care arrangements found for this sample of children from low-income families. Why do families change their arrangements so frequently? The other covariates in the fixed effects regression suggest some of the factors that drive instability. Factors including the number of children, type of care and care availability, as well as family changes such as moving or having a new baby were significantly related to changing primary provider. Parents' survey responses also provide some insight into why child care changes occurred. Most of the responses revolved around practicalities, changes in care needs and family circumstances, including issues such as cost, location, and hours, the care no longer being available, losing a job or moving, a new caregiver (such as a grandparent) becoming available, or children becoming school age. Responses did occasionally relate to child care funding, such as "I lost my child care financing," "MFIP [welfare] ended and lost child care coverage," or "Childcare assistance cut me off," but these were relatively infrequent, at most a few individuals at each wave of the survey. Of the 271 
responses to the question asking why families changed their arrangements, just seven responses (2.6\%) related to losing a child care subsidy.

\section{Patterns of Number of Care Arrangements}

Next we examine the relationship between number of concurrent providers and subsidy receipt. Table 7 presents the number of providers for subsidized and unsubsidized children, as well as the number of subsidized providers for subsidy recipients (based on the administrative data). Multiple arrangements were extremely common for children in this low-income sample. Subsidy recipients tended to have similar numbers of providers overall compared to those not receiving subsidy who were using non-parental care (Table 7). In the pooled sample, both groups averaged 1.8 providers. Although children receiving subsidy had very similar numbers of providers compared to children not receiving subsidy, only some of those providers were subsidized. While the number of providers for subsidy recipients in the pooled sample was 1.8 , the number of subsidized providers (identified using the subsidy administrative data) was only 1.1. While the subsidy program was supporting at least one provider for subsidy recipients, around half of subsidy recipients had an additional, unsubsidized arrangement.

Table 8 presents the patterns of number of arrangements across types of care, as well as in non-parental care overall, by subsidy receipt, pooling all the waves. Across all the waves, $43 \%$ of children were in center care, $35 \%$ were using in-home care, and $39 \%$ were in out-of-home care, with some children in multiple types of care. There was an average of $14 \%$ of children with no regular non-parental care (parental care only). Comparing subsidy recipients and nonrecipients, those receiving subsidy were much more likely to be using center care (68\% of subsidy recipients, $28 \%$ of non-recipients), slightly less likely to be using in-home care (29\% of subsidy recipients, $38 \%$ of non-recipients), and equally likely to be in out-of-home care. While 
$3 \%$ of subsidy recipients reported using parental care only (probably due to the slightly different time frames for the survey (two weeks) and administrative data (one calendar month), $21 \%$ of non-recipients were in parental care only. Although subsidy recipients and non-recipients used somewhat different types of care, they were very similar in the number of providers they used when they used a particular care type. Specifically, both subsidy recipients and non-recipients used about 1.5 in-home providers and about 1.4 to 1.5 out-of-home providers when they used these types of care (Table 8).

\section{Fixed Effects Model of the Number of Providers}

Table 9 presents the estimation results for the OLS child fixed effects model where the dependent variable is the number of providers concurrently caring for the child on a regular basis. The sample for this model was 239 children with 898 observations. The results show that subsidy receipt was not related to the number of providers families used for the focal child: the estimated coefficient indicates those receiving subsidy used 0.032 fewer providers, and was not statistically significant. Only one estimated coefficient was significant in the model, which suggests families use multiple providers for reasons that do not change substantially over time. After controlling for unobserved characteristics of children in the fixed effects model, there was no evidence that subsidy receipt changed the number of providers used concurrently.

Why do families use these multiple arrangements? The survey asked parents who used multiple types of child care why they did so as an open ended question. By far the most common responses related to the availability of care, such as centers not being open evenings or weekends, or Head Start not covering all the hours of care needed. These responses suggest that in some cases multiple arrangements were not desired, but were necessary to meet care needs. In other cases, however, multiple child care arrangements were due to parents' preferences. For instance, 
"so she can spend time with her grandparents" was one response, along with "to interact/play with other kids." Using multiple arrangements may be due to parental preferences for diverse experiences rather than availability or affordability constraints in some cases, and does not seem to be related to subsidy receipt.

\section{Patterns of Perceived Quality of Care}

In this section we examine the relationship between the quality factor and receiving a child care subsidy. Table 10 presents the mean value of the quality factor by subsidy status and also by type of care at each wave, for the primary child care arrangement of those in non-parental care. The units on the quality factor are standard deviations, and the variable, by construction, has an overall mean of zero. Looking across all the waves, children receiving subsidies have a 0.3 standard deviation (SD) quality factor, while unsubsidized children have a -0.2 SD quality factor. Thus children receiving subsidies were in primary arrangements where the quality factor was higher by approximately half a standard deviation. The exact difference varied across the waves, but this pattern held in all the waves.

Differences in the mean factor for subsidized versus unsubsidized children varied across the types of care. The average quality factor for children whose primary provider was a center was the same for both subsidized and unsubsidized children (about 0.6). Subsidized children in family child care have a slightly higher average value of the quality factor, by $0.1 \mathrm{SD}$, compared to unsubsidized children. Those children receiving subsidies and in family, friend or neighbor care reported slightly higher quality than those not receiving subsidies, -0.4 versus -0.6 .

\section{Fixed Effects Model for Perceived Quality of Care}

Although the average quality factor was higher for children receiving subsidies than for non-recipients, this comparison does not control for observed and unobserved characteristics of 
the children and families. Table 11 presents fixed effects OLS regressions for the quality factor. The sample for this model was 205 children and 703 observations. In the first column, which does not include controls for type of care, subsidy receipt predicted a significantly higher level of the quality factor, by 0.54 standard deviations. Most of this effect was mediated through increased access to centers, as seen in the second column. Other types of care have significantly lower quality factors than centers, particularly family, friend, or neighbor care. The effect of subsidy receipt itself remains significant in the model including type of care controls, a $0.15 \mathrm{SD}$ increase in perceived quality. The results demonstrate a direct effect of subsidy receipt on the quality factor in addition to the effect mediated through selecting centers rather than other types of care.

Because the quality factor is a construct based on a number of different questions, we tested the sensitivity of our findings to different specifications of the factor. Specifically, we tested alternative subsets of the 17 questions asked about the care setting and the child's experience. First we estimated the model using a factor based on only responses to the questions on the child's experience (items a-g in Table 1), as these questions may be less dependent on a particular type of care setting. We also tested a factor with items a-g (child's experience) and h, j, and $\mathrm{k}$ (talking with the provider, having books and learning materials, and a warm and caring environment) based on a similar principle. With both of these alternative specifications, we see a positive and significant effect of subsidy receipt on perceived quality before types of care are added, and a positive but insignificant effect of subsidy once the differences mediated through use of centers are controlled for by adding type of care. The effect sizes are, unsurprisingly, smaller, since with fewer variables the underlying construct is measured less precisely. However, 
the overall result of a positive impact from subsidy, mediated through parents selecting centers when financially supported by a subsidy, remains.

\section{Discussion}

Changes to CCDF as part of the Child Care and Development Block Grant Act of 2014 emphasize the importance of child care quality and stability of care (Matthews, Schulman, Vogtman, Johnson-Staub, \& Blank, 2015). Whether subsidies support stability and quality is therefore an important question to researchers and policymakers. In this study we found that participation in the child care subsidy program did not impact the stability of care or change the number of concurrent providers for low-income families in Minnesota. Subsidy receipt did lead to a higher reported quality of care. Low-income parents, when given additional financial resources, were more likely to use center-based care and they reported higher quality (in both center and family child care) based on a number of structural and process dimensions of quality.

There is an important avenue for future research in understanding why subsidy participation — despite providing additional financial resources to the family — does not appear to contribute to stability in care arrangements. While median durations of subsidized arrangements were short (6 months), subsidy recipients were not more likely to change care; rather, lowincome children typically had short arrangements and high rates of instability, regardless of subsidy receipt. The result that subsidy receipt had essentially no effect on the subsequent stability of care could be the net effect of elements of the subsidy program that could increase stability and other elements of the program that could decrease stability. The added financial resources of subsidy receipt as an ongoing source of support to pay for child care could lead parents to choose arrangements with greater stability. At the same time, policy or administrative barriers that lead to the loss of subsidy could decrease the subsequent stability of care. For 
instance, income eligibility limits may result in families losing subsidies temporarily, if income fluctuates (Adams \& Rohacek, 2010).

Another aspect of subsidy policy that may influence the stability of care arrangements is the requirement to re-certify eligibility at frequent intervals, which may act as an administrative barrier to continuity of subsidy and thus affect the continuity of care (Adams \& Rohacek, 2010). Multiple studies have found that children were more likely to exit subsidy when they had to recertify their eligibility (Davis et al., 2016; Grobe et al., 2008; Ha \& Meyer, 2010;

Michalopoulos et al., 2010; Weber et al., 2014). Policies such as lengthening eligibility periods therefore may help subsidy increase the stability of care. Redesigning eligibility policies so that parents can remain eligible to receive subsidy during temporary income, employment, or family changes may also improve stability. While the Child Care and Development Block Grant Act of 2014 makes some changes such as 12-month eligibility periods and allowing for temporary employment or income fluctuations, it may also be that child care stability is difficult to promote through subsidy policy. Parents rarely attributed child care changes to financial issues, thus there may be a limited scope for subsidy to increase stability by improving financing for child care. Other studies have found that the reasons respondents give for changing care and the predictors of care changes are multi-faceted and complex (Chaudry, 2004; Davis, Carlin, et al., 2014; Henly et al., 2015).

These findings confirm earlier work (Davis, Carlin, et al., 2014), which demonstrated, albeit without the benefit of fixed effects methods to correct for selection, that those who initially were receiving a subsidy were no more or less likely to change primary providers. The previous study found that those receiving a subsidy were less likely to change type of care; this may be related to our finding that parents are more likely to choose centers when subsidized if parents 
are better able to access preferred care arrangements with a subsidy. However, receipt of a subsidy does not appear to be funding or fully meeting all of children's child care needs. Use of multiple arrangements was common for both children who did and did not receive subsidies. Not all use of multiple providers is necessarily problematic; parents also may want to expose their children to a variety of care and education environments (Speirs, Vesely, \& Roy, 2015).

Previous research indicates that parents may not be able to identify subtle differences in process quality or may overestimate quality when compared to expert observers' assessments (Cryer, Tietze, \& Wessels, 2002; Mocan, 2007). Yet, in this study, parents discerned features of care that are known to be associated with quality and children's outcomes and that also vary by type of care (Li-Grining \& Coley, 2006; NICHD Early Child Care Research Network, 2004). When asked a series of questions on the characteristics of care, parents' responses over time varied by type of child care setting, suggesting that parents were able to distinguish whether children were experiencing particular elements of quality care. Though the distinctions aligned with features of care expected in high quality settings, it is important to note that this finding does not imply that children in this study were experiencing excellent care. Though observations were not available in this study, an evaluation of early care and education program quality in Minnesota (Tout et al., 2016) and analyses of national data (e.g. Abner, Gordon, Kaestner, \& Korenman, 2013) indicate that average scores on observed quality across child care centers and family child care programs are in the middle- to low-range. A recent synthesis of research on public pre-kindergarten concludes that excellent quality is available in a small percentage of settings and that instructional quality is of particular concern (Yoshikawa et al., 2013).

The results also indicate that in the absence of a subsidy, cost constrains parents' choices to lower-quality options. Subsidy receipt decreased constraints, which led parents to select center 
care for their children more often, and which drove much of the quality effect. Other research has found that parents perceive centers to be higher quality and that parents emphasizing care quality or learning as their priority are more likely to choose centers (Coley et al., 2014; Kim \& Fram, 2009). There was also an increase in the quality factor when receiving subsidies after controlling for type of care, indicating that even within care types, subsidy receipt allows parents to select higher quality of care. Overall, subsidy receipt had a sizeable impact on elements of the quality of care children experience, in part by allowing families to access and select higher quality types of care. While studies have demonstrated that low income families may be constrained in choosing higher quality providers (Fuller, Kagan, Caspary, \& Gauthier, 2002; Shlay, Tran, Weinraub, \& Harmon, 2005) our results suggest that families did have higher perceived quality options to switch to when receiving a subsidy.

\section{Study Strengths and Limitations}

A particularly valuable element of this study is the use of longitudinal data on children and families and the findings' robustness to selection and unobservable characteristics of children and families. When examining the same families making decisions over time, using child fixed effects removes the problem of selection on any unobservable characteristics that do not change over time, and therefore accounts for any time-invariant aspects of preferences for certain characteristics of care. While decisions and preferences may evolve in response to child age, work, or other care alternatives being available, we control for these important time-varying characteristics. The main limitation of the approach is that if there are unobserved characteristics that vary over time and are related to both subsidy receipt and the outcomes, the results can still be biased. So, for instance, if parental preferences are changing over time in unobservable ways that affect both subsidy receipt and the outcomes, this may bias results. An interesting area for 
future research is investigating how and how much parental preferences evolve over time, as well as why they change.

An important limitation of this research is that we were unable to obtain observational measures of quality of care arrangements. The quality factor used as an outcome measure in this study was based on parent reports. Fortunately, the level of detail in the questions about the focal child's care arrangements reflected elements of quality included in Minnesota's QRIS and allowed us to identify key elements of the care setting that are likely to be related to observational quality measures (Hestenes et al., 2015; Tout et al., 2016). The modest sample size and attrition across waves of the survey are also limitations, although the relative consistency of time-invariant characteristics between the baseline and pooled samples suggests any attrition bias is likely to be small. We have data from only one state, and parent preferences about care and take-up of subsidy may differ from states with different policy and economic environments. Nonetheless, our key results concur with those of Ryan et al. (2011) and Johnson et al. (2012) who find that subsidy recipients in a nationally representative sample used higher quality care because they were more likely to use center-based care.

This paper focused on the care arrangements subsidized through CCDF vouchers. We were unable to explicitly examine additional or alternative forms of care, such as public prekindergarten or Head Start programs, which other studies have found to have differential effects on children's development (Currie \& Neidell, 2007; Forry, Davis, \& Welti, 2013). Johnson, Ryan and Brooks-Gunn (2012) find that children who are in Head Start or public prekindergarten experience higher quality care than children who received child care subsidies. Other research has argued that children's development or health may be harmed when families receive child care subsidies, because of the use of low-quality care in place of parental care 
(Herbst \& Tekin, 2010, 2011, 2012). Although we are not comparing the quality of child care to the alternative of parental care only, the availability of subsidies provides parents who use nonparental care the ability to select higher quality care by reducing their financial constraints.

Another limitation of this study is that we do not directly test the relationship between subsidy participation and child development outcomes. While we find subsidy receipt leads to similar stability and use of higher quality care and we would therefore expect improvements in child development outcomes, this relationship cannot be directly tested with the available data. In other studies that estimate the impact of subsidy on children's developmental outcomes, some negative effects of subsidy have been found, but the relationships observed could well be due to selection into the subsidy program (e.g., Hawkinson et al., 2013). An important direction for future research is therefore studies that focus directly on subsidy's impact on child development, but fully account for selection, for example by using fixed effects models.

\section{Conclusion}

This paper examined whether the receipt of child care subsidies affects reported quality and stability of care, using longitudinal data on children from low-income families in Minnesota. Child fixed effects models were used to generate estimates of the impact of the subsidy program. Child care subsidies were shown to have no net effect on child care stability or the number of providers used; both instability and multiplicity are high for children in low-income families regardless of subsidy status. Children receiving child care subsidies did experience elements of higher quality care, primarily due to increased use of center care. These results indicate that the subsidy program may have some positive effects on child outcomes through its impact on quality of care used by low-income families. 


\section{References}

Abner, K. S., Gordon, R. A., Kaestner, R., \& Korenman, S. (2013). Does child-care quality mediate associations between type of care and development? Journal of Marriage and Family, 75(5), 1203-1217. http://doi.org/10.1111/jomf.12055

Adams, G., \& Rohacek, M. (2002). More than a work support? Issues around integrating child development goals into the child care subsidy system. Early Childhood Research Quarterly, 17(4), 418-440. http://doi.org/10.1016/S0885-2006(02)00184-9

Adams, G., \& Rohacek, M. (2010). Child Care Instability: Definitions, Context, and Policy Implications. Washington, DC: Urban Institute.

Administration for Children and Families Department of Health and Human Services. (2014). CCDF Reauthorization. Retrieved from http://www.acf.hhs.gov/programs/occ/ccdfreauthorization

Ansari, A., \& Winsler, A. (2013). Stability and sequence of center-based and family childcare: Links with low-income children's school readiness. Children and Youth Services Review, 35(2), 358-366. http://doi.org/10.1016/j.childyouth.2012.11.017

Bassok, D., Fitzpatrick, M., Greenberg, E., \& Loeb, S. (2016). Within- and Between-Sector Quality Differences in Early Childhood Education and Care. Child Development, O(0), 1-19. http://doi.org/10.1111/cdev.12551

Becker, G. S. (1981). A Treatise on the Family. Cambridge, MA: Harvard University Press.

Belsky, J., Vandell, D. L., Burchinal, M. R., Clarke-Stewart, K. A., McCartney, K., \& Owen, M. T. (2007). Are there long-term effects of early child care? Child Development, 78(2), 681701. http://doi.org/10.1111/j.1467-8624.2007.01021.x

Berger, M. C., \& Black, D. A. (1992). Child care subsidies, quality of care, and the labor supply of low-income, single mothers. The Review of Economics and Statistics, 74(4), 635-642.

Bigras, N., Bouchard, C., Cantin, G., Brunson, L., Coutu, S., Lemay, L., ... Charron, A. (2010). A Comparative Study of Structural and Process Quality in Center-Based and Family-Based Child Care Services. Child \& Youth Care Forum, 39(3), 129-150. http://doi.org/10.1007/s10566-009-9088-4

Blau, D. (1999). The effect of income on child development. Review of Economics and Statistics, 81(2), 261-276.

Burchinal, M. R., \& Nelson, L. (2000). Family selection and child care experiences: implications for studies of child outcomes. Early Childhood Research Quarterly, 15(3), 385-411. http://doi.org/10.1016/S0885-2006(00)00072-7

Burstein, N., \& Layzer, J. I. (2007). National Study of Child Care for Low-Income Families: Patterns of child care use among low-income families: Final report. Cambridge, MA: Abt Associates, Inc.

Campbell, F. A., Ramey, C. T., Pugnello, E., Sparling, J., \& Miller-Johnson, S. (2002). Early Childhood Education: Young Adult Outcomes From the Abecedarian Project. Applied Developmental Science, 6(1), 42-57. http://doi.org/10.1207/S1532480XADS0601 
Casper, L. M., \& Smith, K. E. (2004). Self-care: why do parents leave their children unsupervised? Demography, 41(2), 285-301. http://doi.org/10.1353/dem.2004.0013

Chaudry, A. (2004). Putting Children First: How Low-Wage Working Mothers Manage Child Care. New York, NY: Russell Sage Foundation.

Chaudry, A., Henly, J. R., \& Meyers, M. K. (2010). Conceptual Frameworks for Child Care Decision-Making. Washington, DC.

Chaudry, A., Pedroza, J. M., Sandstrom, H., Anna, D., Grosz, M., Scott, M., \& Ting, S. (2011). Child Care Choices of Low-Income Working Families. Washington, DC.

Claessens, A., \& Chen, J.-H. (2013). Multiple child care arrangements and child well being: Early care experiences in Australia. Early Childhood Research Quarterly, 28(1), 49-61. http://doi.org/10.1016/j.ecresq.2012.06.003

Coley, R. L., Votruba-Drzal, E., Collins, M. A., \& Miller, P. (2014). Selection into early education and care settings: Differences by developmental period. Early Childhood Research Quarterly, 29(3), 319-332. http://doi.org/10.1016/j.ecresq.2014.03.006

Connelly, R. (1992). The Effect of Child Care Costs on Married Women's Labor Force Participation. The Review of Economics and Statistics, 74(1), 83-90.

Crosby, D. A., Gennetian, L., \& Huston, A. C. (2005). Child Care Assistance Policies Can Affect the Use of Center-Based Care for Children in Low-Income Families. Applied Developmental Science, 9(2), 86-106.

Cryer, D., Tietze, W., \& Wessels, H. (2002). Parents' perceptions of their children' s child care: a cross-national comparison. Early Childhood Research Quarterly, 17, 259-277.

Currie, J., \& Neidell, M. (2007). Getting inside the "Black Box" of Head Start quality: What matters and what doesn't. Economics of Education Review, 26(1), 83-99. http://doi.org/10.1016/j.econedurev.2005.03.004

Davis, E. E., Carlin, C. S., \& Krafft, C. (2014). Time for a change? Predictors of child care changes by low-income families. Journal of Children and Poverty, 20(1), 21-45.

Davis, E. E., \& Connelly, R. (2005). The influence of local price and availability on parents' choice of child care. Population Research and Policy Review, 24(4), 301-334. http://doi.org/10.1007/s11113-005-8515-y

Davis, E. E., Krafft, C., \& Forry, N. D. (2016). The Role of Policy and Practice in Short Spells of Child Care Subsidy Participation. Journal of Public Administration Research and Theory, muw039. http://doi.org/10.1093/jopart/muw039

Davis, E. E., Krafft, C., \& Tout, K. (2014). Stability of Subsidy Use and Continuity of Care in the Child Care Assistance Program in Minnesota. Bethesda, MD: Child Trends.

Dearing, E., McCartney, K., \& Taylor, B. A. (2009). Does Higher Quality Early Child Care Promote Low-Income Children's Math and Reading Achievement in Middle Childhood? Child Development, 80(5), 1329-1349.

de Schipper, J. C., Van Ijzendoorn, M. H., \& Tavecchio, L. W. C. (2004). Stability in Center Day Care: Relations with Children's Well-being and Problem Behavior in Day Care. Social 
Development, 13(4), 531-550.

Dowsett, C. J., Huston, A. C., Imes, A. E., \& Gennetian, L. (2008). Structural and process features in three types of child care for children from high and low income families. Early Childhood Research Quarterly, 23(1), 69-93. http://doi.org/10.1016/j.ecresq.2007.06.003

Emlen, A. C., Koren, P. E., \& Schultze, K. H. (2000). A Packet of Scales for Measuring Quality of Child Care From a Parent's Point of View with Summary of Method and Findings. Portland, OR: Portland State University and the Oregon Child Care Research Partnership.

Ertas, N., \& Shields, S. (2012). Child care subsidies and care arrangements of low-income parents. Children and Youth Services Review, 34(1), 179-185.

Forry, N. D., Davis, E. E., \& Welti, K. (2013). Ready or not: Associations between participation in subsidized child care arrangements, pre-kindergarten, and Head Start and children's school readiness. Early Childhood Research Quarterly, 28(3), 634-644.

Fuller, B., Kagan, S. L., Caspary, G. L., \& Gauthier, C. A. (2002). Welfare reform and child care options for low-income families. The Future of Children, 12(1), 96-119.

Fuller, B., Kagan, S. L., Loeb, S., \& Chang, Y. W. (2004). Child care quality: Centers and home settings that serve poor families. Early Childhood Research Quarterly, 19(4), 505-527. http://doi.org/10.1016/j.ecresq.2004.10.006

Gordon, R. A., \& Hognas, R. S. (2006). The best laid plans: Expectations, preferences, and stability of child-care arrangements. Journal of Marriage and Family, 68(2), 373-393. http://doi.org/10.1111/j.1741-3737.2006.00259.x

Grobe, D., Weber, R. B., \& Davis, E. E. (2008). Why Do They Leave? Child Care Subsidy Use in Oregon. Journal of Family and Economic Issues, 29(1), 110-127.

Ha, Y., Magnuson, K., \& Ybarra, M. (2012). Patterns of child care subsidy receipt and the stability of child care. Children and Youth Services Review, 34(9), 1834-1844. http://doi.org/10.1016/j.childyouth.2012.05.016

Ha, Y., \& Meyer, D. R. (2010). Child care subsidy patterns: Are exits related to economic setbacks or economic successes? Children and Youth Services Review, 32(3), 346-355.

Hawkinson, L. E., Griffen, A. S., Dong, N., \& Maynard, R. A. (2013). The relationship between child care subsidies and children's cognitive development. Early Childhood Research Quarterly, 28(2), 388-404.

Henly, J. R., Sandstrom, H., Claessens, A., Pilarz, A. R., Gelatt, J., Kim, J., \& Healy, O. (2015). Determinants of Subsidy Stability and Child Care Continuity. Washington, DC: Urban Institute.

Herbst, C. M. (2008). Who are the eligible non-recipients of child care subsidies? Children and Youth Services Review, 30(9), 1037-1054.

Herbst, C. M., \& Tekin, E. (2010). Child care subsidies and child development. Economics of Education Review, 29(4), 618-638.

Herbst, C. M., \& Tekin, E. (2011). Child care subsidies and childhood obesity. Review of Economics of the Household, 9(3), 349-378. 
Herbst, C. M., \& Tekin, E. (2012). The geographic accessibility of child care subsidies and evidence on the impact of subsidy receipt on childhood obesity. Journal of Urban Economics, 71(1), 37-52.

Hestenes, L. L., Kintner-Duffy, V., Wang, Y. C., La Paro, K., Mims, S. U., Crosby, D., ... Cassidy, D. J. (2015). Comparisons among quality measures in child care settings: Understanding the use of multiple measures in North Carolina's QRIS and their links to social-emotional development in preschool children. Early Childhood Research Quarterly, 30, 199-214. http://doi.org/10.1016/j.ecresq.2014.06.003

Howes, C., \& Hamilton, C. E. (1992). Children's Relationships with Child Care Teachers: Stability and Concordance with Parental Attachments. Child Development, 63(4), 867-878.

Johnson, A. D., \& Herbst, C. M. (2013). Can we trust parental reports of child care subsidy receipt? Children and Youth Services Review, 35(6), 984-993.

Johnson, A. D., Martin, A., \& Brooks-Gunn, J. (2011). Who uses child care subsidies? Comparing recipients to eligible non-recipients on family background characteristics and child care preferences. Children and Youth Services Review, 33(7), 1072-1083.

Johnson, A. D., Ryan, R. M., \& Brooks-Gunn, J. (2012). Child-Care Subsidies: Do They Impact the Quality of Care Children Experience? Child Development, 83(4), 1444-1461.

Jones-Branch, J. A., Torquati, J. C., Raikes, H., \& Edwards, C. P. (2004). Child Care Subsidy and Quality Child Care Subsidy and Quality. Early Education \& Development, 15(3), 327342. http://doi.org/10.1207/s15566935eed1503

Kim, J., \& Fram, M. S. (2009). Profiles of choice: Parents' patterns of priority in child care decision-making. Early Childhood Research Quarterly, 24(1), 77-91. http://doi.org/10.1016/j.ecresq.2008.10.001

Krafft, C., Davis, E. E., \& Tout, K. (2014). Changes in Child Care Arrangements of Young Children in Maryland. Bethesda, MD: Child Trends.

Krafft, C., Davis, E. E., \& Tout, K. (2015). The Problem of Measurement Error in Self-Reported Receipt of Child Care Subsidies: Evidence from Two States. Social Service Review, 89(4), 686-726.

Krafft, C., Davis, E. E., Tout, K., \& Forry, N. D. (2013). Changes in Child Care Arrangements in Minnesota. Bethesda, MD: Child Trends.

Li-Grining, C. P., \& Coley, R. L. (2006). Child care experiences in low-income communities: Developmental quality and maternal views. Early Childhood Research Quarterly, 21(2), 125-141. http://doi.org/10.1016/j.ecresq.2006.04.001

Loeb, S., Fuller, B., Kagan, S. L., \& Carrol, B. (2004). Child Care in Poor Communities: Early Learning Effects of Type, Quality, and Stability. Child Development, 75(1), 47-65.

Lowe, E. D., Weisner, T. S., Geis, S., \& Huston, A. C. (2005). Child Care Instability and the Effort to Sustain a Working Daily Routine: Evidence from the New Hope Ethnographic Study of Low-Income Families. In Developmental Pathways Through Middle Childhood (pp. 121-144). 
Marshall, N. L., Robeson, W. W., Tracy, A. J., Frye, A., \& Roberts, J. (2013). Subsidized child care, maternal employment and access to quality, affordable child care. Early Childhood Research Quarterly, 28(4), 808-819. http://doi.org/10.1016/j.ecresq.2013.07.008

Matthews, H., \& Schmit, S. (2014). Child Care Assistance Spending and Participation in 2012. Washington, DC: CLASP.

Matthews, H., Schulman, K., Vogtman, J., Johnson-Staub, C., \& Blank, H. (2015). Implementing the Child Care and Development Block Grant Reauthorization: A Guide for States. Washington, DC: Center for Law and Social Policy (CLASP); National Women's Law Center.

McCartney, K., Dearing, E., Taylor, B. A., \& Bub, K. L. (2007). Quality Child Care Supports the Achievement of Low-Income Children: Direct and Indirect Pathways Through Caregiving and the Home Environment. Journal of Applied Developmental Psychology, 28(5-6), 411426. http://doi.org/10.1016/j.appdev.2007.06.010

Meyers, M. K., \& Jordan, L. P. (2006). Choice and accommodation in parental child care decisions. Journal of the Community Development Society, 37(2). http://doi.org/10.1080/15575330609490207

Michalopoulos, C., Lundquist, E., \& Castells, N. (2010). The effects of child care subsidies for moderate-income families in Cook County, Illinois. OPRE 2011-3, Washington, DC: Office of Planning, Research and Evaluation, Administration for Children and Families, U.S. Department of Health and Human Services.

Mocan, N. (2007). Can consumers detect lemons? An empirical analysis of information asymmetry in the market for child care. Journal of Population Economics, 20(4), 743-780. http://doi.org/10.1007/s00148-006-0087-6

Morrissey, T. W. (2008). Familial Factors Associated With the Use of Multiple Child-Care Arrangements. Journal of Marriage and Family, 70(2), 549-563.

Morrissey, T. W. (2009). Multiple Child-Care Arrangements and Young Children's Behavioral Outcomes. Child Development, 80(1), 59-76.

Morrissey, T. W. (2010). Sequence of child care type and child development: What role does peer exposure play? Early Childhood Research Quarterly, 25(1), 33-50. http://doi.org/10.1016/j.ecresq.2009.08.005

NICHD Early Child Care Research Network. (2002). Early Child Care and Children's Development Prior to School Entry: Results from the NICHD Study of Early Child Care. American Educational Research Journal, 39(1), 133-164. http://doi.org/10.3102/00028312039001133

NICHD Early Child Care Research Network. (2004). Type of child care and children's development at 54 months. Early Childhood Research Quarterly, 19, 203-230. http://doi.org/10.1016/j.ecresq.2004.04.002

Office of Child Care. (2015). Child Care and Development Fund Plan (CCDF) Report to Congress for FY 2012-FY 2013. Washington, DC.

Pilarz, A. R., Claessens, A., \& Gelatt, J. (2016). Patterns of child care subsidy use and stability 
of subsidized care arrangements: Evidence from Illinois and New York. Children and Youth Services Review, 65, 231-243. http://doi.org/10.1016/j.childyouth.2016.04.011

Pilarz, A. R., \& Hill, H. D. (2014). Unstable and multiple child care arrangements and young children's behavior. Early Childhood Research Quarterly, 29(4), 471-483. http://doi.org/10.1016/j.ecresq.2014.05.007

Raikes, H., Torquati, J., Jung, E., Peterson, C., Atwater, J., Scott, J., \& Messner, L. (2013). Family child care in four Midwestern states: Multiple measures of quality and relations to outcomes by licensed status and subsidy program participation. Early Childhood Research Quarterly, 28(4), 879-892. http://doi.org/10.1016/j.ecresq.2013.06.001

Reynolds, A. J., \& Temple, J. A. (1998). Extended Early Childhood Intervention and School Achievement: Age Thirteen Findings from the Chicago Longitudinal Study. Child Development, 69(1), 231-246.

Ryan, R. M., Johnson, A. D., Rigby, E., \& Brooks-Gunn, J. (2011). The Impact of Child Care Subsidy Use on Child Care Quality. Early Childhood Research Quarterly, 26(3), 320-331.

Sandstrom, H., \& Huerta, S. (2013). The Negative Effects of Instability on Child Development: A Research Synthesis (No. 3). Low-Income Working Families Discussion Paper. Washington DC: Urban Institute.

Schweinhart, L. J., \& Weikart, D. P. (1998). High/Scope Perry Preschool Program Effects at Age Twenty-Seven. In J. Crane (Ed.), Social Programs that Work. New York, NY: Russell Sage Foundation.

Scott, E. K., London, A. S., \& Hurst, A. (2005). Instability in patchworks of child care when moving from welfare to work. Journal of Marriage and Family, 67(2), 370-386. http://doi.org/10.1111/j.0022-2445.2005.00122.x

Shlay, A. B., Tran, H., Weinraub, M., \& Harmon, M. (2005). Teasing apart the child care conundrum: A factorial survey analysis of perceptions of child care quality, fair market price and willingness to pay by low-income, African American parents. Early Childhood Research Quarterly, 20(4), 393-416. http://doi.org/10.1016/j.ecresq.2005.10.002

Speirs, K. E., Vesely, C. K., \& Roy, K. (2015). Is stability always a good thing? Low-income mothers' experiences with child care transitions. Children and Youth Services Review, 53, 147-156. http://doi.org/10.1016/j.childyouth.2015.03.026

Swenson, K. (2014). Child Care Subsidy Duration and Caseload Dynamics: A Multi-State Examination. U.S. Department of Health and Human Services, Office of the Assistant Secretary for Planning and Evaluation.

Tang, S., Coley, R. L., \& Votruba-Drzal, E. (2012). Low-income families' selection of child care for their young children. Children and Youth Services Review, 34(10), 2002-2011. http://doi.org/10.1016/j.childyouth.2012.06.012

Tekin, E. (2005). Child care subsidy receipt, employment, and child care choices of single mothers. Economics Letters, 89(1), 1-6.

Tout, K., Cleveland, J., Li, W., Starr, R., Soli, M., \& Bultnick, E. (2016). Parent Aware: Minnesota's Quality Rating and Improvement System: Initial Validation Report. Bethesda, 
MD: Child Trends.

Tout, K., Forry, N. D., Blasberg, A., Isner, T., Carlin, C., \& Davis, E. E. (2011). Minnesota Child Care Choices: Study and Sample Description. Bethesda, MD: Child Trends.

Tran, H., \& Weinraub, M. (2006). Child care effects in context: quality, stability, and multiplicity in non-maternal child care arrangements during the first 15 months of life. Developmental Psychology, 42(3), 566-82.

U.S. Senate Committee on Health Education Labor and Pensions. (2014). Child Care and Development Block Grant Act of 2014 (No. 113-138). Report.

Weber, R. B. (2005). Measurement of Child Care Arrangement Stability: A Review and Case Study Using Oregon Child Care Subsidy Data. Oregon State University.

Weber, R. B., Grobe, D., \& Davis, E. E. (2014). Does policy matter? The effect of increasing child care subsidy policy generosity on program outcomes. Children and Youth Services Review, 44, 135-144. http://doi.org/10.1016/j.childyouth.2014.06.010

Weinraub, M., Shlay, A. B., Harmon, M., \& Tran, H. (2005). Subsidizing child care: How child care subsidies affect the child care used by low-income African American families. Early Childhood Research Quarterly, 20(4), 373-392.

Wolfe, B., \& Scrivner, S. (2004). Child care use and parental desire to switch care type among a low-income population. Journal of Family and Economic Issues, 25(2), 139-162.

Yoshikawa, H., Weiland, C., Brooks-Gunn, J., Burchinal, M. R., Espinosa, L. M., Gormley, W. T., ... Zaslow, M. J. (2013). Investing in Our Future: The Evidence Base on Preschool Education. Society for Research in Child Development and Foundation for Child Development. 
Tables

Table 1. Distribution of responses to survey questions used in the quality factor analysis, factor loadings, uniqueness, and scoring coefficients

\begin{tabular}{|c|c|c|c|c|c|c|c|c|}
\hline \multicolumn{6}{|c|}{ Distribution of Responses } & \multicolumn{3}{|c|}{ Factor Analysis } \\
\hline & Never & Rarely & Sometimes & Usually & Always & $\begin{array}{r}\text { Factor } \\
\text { Loading }\end{array}$ & Uniqueness & $\begin{array}{r}\text { Scoring } \\
\text { Coefficient }\end{array}$ \\
\hline \multicolumn{9}{|l|}{$\begin{array}{l}\text { Please think about when [child] is at [primary provider] and choose the } \\
\text { answer that best represents the experience you believe [child] is having } \\
\text { there: }\end{array}$} \\
\hline a. My child gets a lot of positive, individual attention & 0.1 & 0.4 & 7.6 & 23.5 & 68.4 & 0.18 & 0.97 & 0.04 \\
\hline b. My child likes the caregiver or provider & 0.1 & 0.3 & 2.9 & 8.3 & 88.4 & 0.24 & 0.94 & 0.05 \\
\hline $\begin{array}{l}\text { c. There are lots of creative activities such as art, music, dance, } \\
\text { and drama }\end{array}$ & 2.2 & 3.3 & 16.5 & 15.5 & 62.5 & 0.62 & 0.61 & 0.13 \\
\hline $\begin{array}{l}\text { d. The caregiver provides activities that are right for my child and } \\
\text { fit my child's needs }\end{array}$ & 0.8 & 0.6 & 7.1 & 15.4 & 76.1 & 0.56 & 0.69 & 0.13 \\
\hline e. My child is learning new things and new skills & 1.4 & 1.0 & 9.0 & 12.6 & 76.0 & 0.60 & 0.64 & 0.13 \\
\hline f. My child gets a chance to run around and play outside & 3.3 & 3.8 & 16.0 & 17.3 & 59.6 & 0.32 & 0.90 & 0.05 \\
\hline g. My child watches television more than one hour each day & 28.8 & 25.9 & 28.6 & 6.6 & 10.0 & -0.19 & 0.96 & -0.02 \\
\hline \multicolumn{9}{|l|}{ How often would you say [primary provider] does each of these things: } \\
\hline h. Talk with you? & 0.8 & 0.6 & 6.7 & 10.0 & 81.8 & 0.14 & 0.98 & 0.03 \\
\hline i. Use a curriculum or planning tool for teaching? & 9.5 & 6.9 & 18.6 & 14.1 & 51.0 & 0.74 & 0.46 & 0.19 \\
\hline j. Have a lot of books and learning materials? & 2.3 & 1.7 & 6.9 & 12.6 & 76.6 & 0.56 & 0.69 & 0.10 \\
\hline $\begin{array}{l}\text { k. Provide a warm and caring environment with positive } \\
\text { relationships between teachers and caregivers and children? }\end{array}$ & 0.4 & 0.4 & 2.3 & 4.2 & 92.8 & 0.25 & 0.94 & 0.06 \\
\hline 1. Help your child get along with other children? & 2.4 & 1.3 & 5.1 & 9.5 & 81.7 & 0.34 & 0.89 & 0.05 \\
\hline $\begin{array}{l}\text { m. Track your child's learning and development using an } \\
\text { assessment tool? }\end{array}$ & 22.6 & 8.4 & 14.6 & 11.8 & 42.6 & 0.69 & 0.52 & 0.15 \\
\hline $\begin{array}{l}\text { n. Have teachers and caregivers with formal education and } \\
\text { training to work with young children? }\end{array}$ & 30.7 & 4.8 & 10.4 & 7.5 & 46.5 & 0.72 & 0.48 & 0.21 \\
\hline o. Have staff that are warm and friendly with your child? & 15.9 & 0.5 & 2.0 & 4.6 & 77.0 & 0.42 & 0.82 & 0.07 \\
\hline $\begin{array}{l}\text { p. Enroll children from different backgrounds, for example, race, } \\
\text { ethnicity, and religion? }\end{array}$ & 29.4 & 3.4 & 8.0 & 5.5 & 53.7 & 0.63 & 0.60 & 0.14 \\
\hline $\begin{array}{l}\text { q. Have caregivers or teachers who speak your family's native } \\
\text { language with your child? }\end{array}$ & 7.4 & 0.5 & 3.6 & 2.8 & 85.8 & 0.18 & 0.97 & 0.03 \\
\hline
\end{tabular}

Source: Authors' calculation based on Minnesota survey data. N (observations) $=787$

Notes: Sample characteristics available in the appendix. 
Table 2. Sample characteristics by subsidy status

\begin{tabular}{|c|c|c|c|c|c|c|}
\hline \multirow[b]{2}{*}{ Subsidy status: } & \multicolumn{3}{|c|}{$\underline{\text { Baseline }}$} & \multicolumn{3}{|c|}{$\underline{\text { Pooled }}$} \\
\hline & $\begin{array}{r}\text { No } \\
\text { subsidy }\end{array}$ & Subsidy & Total & $\begin{array}{r}\text { No } \\
\text { Subsidy } \\
\end{array}$ & Subsidy & Total \\
\hline \multicolumn{7}{|l|}{ Type of care } \\
\hline Center & 17.8 & 53.7 & 31.3 & 22.3 & 64.3 & 38.5 \\
\hline FCC & 5.0 & 23.1 & 11.8 & 6.3 & 16.7 & 10.3 \\
\hline FFN & 59.4 & 19.8 & 44.6 & 49.9 & 16.0 & 36.8 \\
\hline Parental care only & 17.8 & 3.3 & 12.4 & 21.4 & 3.0 & 14.3 \\
\hline \multicolumn{7}{|l|}{ Child sex } \\
\hline Female & 52.5 & 48.8 & 51.1 & 50.4 & 49.7 & 50.1 \\
\hline Male & 47.5 & 51.2 & 48.9 & 49.6 & 50.3 & 49.9 \\
\hline \multicolumn{7}{|l|}{ Child age } \\
\hline Infant & 36.1 & 21.5 & 30.7 & 16.4 & 11.7 & 14.6 \\
\hline Toddler & 23.8 & 34.7 & 27.9 & 25.9 & 27.9 & 26.7 \\
\hline Preschooler & 33.7 & 40.5 & 36.2 & 46.4 & 51.7 & 48.5 \\
\hline School age & 6.4 & 3.3 & 5.3 & 11.4 & 8.7 & 10.3 \\
\hline \multicolumn{7}{|l|}{ Child race } \\
\hline White, non-Hispanic & 27.7 & 31.4 & 29.1 & 31.5 & 27.9 & 30.1 \\
\hline Hispanic & 14.4 & 10.7 & 13.0 & 13.5 & 6.6 & 10.9 \\
\hline Non-white, non-Hispanic & 57.9 & 57.9 & 57.9 & 55.0 & 65.4 & 59.0 \\
\hline Single parent & 57.9 & 73.6 & 63.8 & 51.1 & 76.2 & 60.8 \\
\hline \multicolumn{7}{|l|}{ Resp. education } \\
\hline Less than high school & 30.7 & 17.4 & 25.7 & 27.9 & 17.8 & 24.0 \\
\hline High school & 32.7 & 36.4 & 34.1 & 33.8 & 35.0 & 34.2 \\
\hline Some college & 33.7 & 39.7 & 35.9 & 35.1 & 39.8 & 36.9 \\
\hline $\mathrm{BA}+$ & 3.0 & 6.6 & 4.3 & 3.3 & 7.3 & 4.9 \\
\hline \multicolumn{7}{|l|}{ Resp. employment } \\
\hline None & 66.8 & 43.0 & 57.9 & 51.2 & 33.2 & 44.2 \\
\hline Part-time & 14.9 & 23.1 & 18.0 & 15.4 & 17.2 & 16.1 \\
\hline Full-time & 18.3 & 33.9 & 24.1 & 33.4 & 49.7 & 39.7 \\
\hline Resp. in education/training & 21.8 & 28.1 & 24.1 & 18.0 & 24.5 & 20.5 \\
\hline \multicolumn{7}{|l|}{ Household income } \\
\hline Under $\$ 15,000$ & 59.9 & 42.1 & 53.3 & 51.1 & 49.2 & 50.4 \\
\hline$\$ 15,000-\$ 29,999$ & 27.7 & 45.5 & 34.4 & 31.6 & 36.2 & 33.4 \\
\hline$\$ 30,000+$ & 12.4 & 12.4 & 12.4 & 17.2 & 14.6 & 16.2 \\
\hline Welfare & 73.8 & 66.9 & 71.2 & 54.6 & 59.0 & 56.3 \\
\hline $\begin{array}{l}\text { Family or friend available to } \\
\text { care for child }\end{array}$ & 67.8 & 30.6 & 53.9 & 64.0 & 38.9 & 54.3 \\
\hline Total & 100.0 & 100.0 & 100.0 & 100.0 & 100.0 & 100.0 \\
\hline \multicolumn{7}{|l|}{ Means } \\
\hline Number of other adults & 0.83 & 0.62 & 0.75 & 0.81 & 0.57 & 0.72 \\
\hline Number of children under six & 1.42 & 1.52 & 1.46 & 1.42 & 1.39 & 1.41 \\
\hline Number of children 6-12 & 0.36 & 0.42 & 0.38 & 0.50 & 0.45 & 0.48 \\
\hline $\mathbf{N}$ (observations) & 202 & 121 & 323 & 696 & 437 & 1133 \\
\hline
\end{tabular}

Source: Authors' calculation based on Minnesota survey data (characteristics) and administrative data (subsidy status) 
Table 3. Percentage of children who entered or exited the subsidy program between survey waves

\begin{tabular}{lrrrr}
\hline & $\begin{array}{r}\text { \% Exited } \\
\text { subsidy } \\
\text { (initially on } \\
\text { subsidy) }\end{array}$ & $\begin{array}{r}\text { \% Entered } \\
\text { subsidy } \\
\text { (initially not } \\
\text { on subsidy) }\end{array}$ & $\begin{array}{r}\text { Number of } \\
\text { children } \\
\text { initially on } \\
\text { subsidy }\end{array}$ & $\begin{array}{r}\text { Number of } \\
\text { children } \\
\text { initially not } \\
\text { on subsidy }\end{array}$ \\
\hline Wave 1 to 2 & 31.6 & 21.1 & 98 & 152 \\
Wave 2 to 3 & 24.7 & 19.8 & 89 & 121 \\
Wave 3 to 4 & 21.8 & 12.7 & 78 & 110 \\
Wave 4 to 5 & 24.6 & 5.9 & 57 & 85 \\
\hline Pooled & 26.1 & 16.0 & 322 & 468 \\
\hline
\end{tabular}

Source: Authors' calculation based on Minnesota administrative data

Notes: Initial subsidy receipt refers to subsidy receipt during the first of the two waves referred to in each row.

Sample characteristics available in the appendix. 
Table 4. Percentage of children with changes in primary and any provider by wave by subsidy status in initial wave

\begin{tabular}{|c|c|c|c|c|c|c|}
\hline & \multicolumn{2}{|c|}{ Primary provider } & \multicolumn{4}{|c|}{ Any provider } \\
\hline & \multirow{2}{*}{$\begin{array}{r}\text { Not receiving } \\
\text { subsidy }\end{array}$} & \multirow{2}{*}{$\begin{array}{l}\text { Subsidy } \\
\text { recipients }\end{array}$} & \multirow{2}{*}{\multicolumn{2}{|c|}{ Not receiving }} & \multirow{2}{*}{$\begin{array}{r}\text { Subsidy } \\
\text { recipients }\end{array}$} & \multirow[b]{2}{*}{ All } \\
\hline & & & & & & \\
\hline \multicolumn{7}{|l|}{$\begin{array}{l}\text { Percentage } \\
\text { who changed: }\end{array}$} \\
\hline Wave 1 to 2 & 62.5 & 46.9 & 56.4 & 82.9 & 75.5 & 80.0 \\
\hline Wave 2 to 3 & 60.3 & 40.9 & 52.2 & 79.3 & 74.2 & 77.1 \\
\hline Wave 3 to 4 & 52.3 & 38.5 & 46.5 & 68.2 & 74.4 & 70.7 \\
\hline Wave 4 to 5 & 58.8 & 36.8 & 50.0 & 76.5 & 71.9 & 74.7 \\
\hline Pooled & 58.9 & 41.4 & 51.8 & 77.3 & 74.2 & 76.1 \\
\hline \multicolumn{7}{|l|}{$\begin{array}{l}\text { Number of } \\
\text { observations: }\end{array}$} \\
\hline Wave 1 to 2 & 152 & 98 & 250 & 152 & 98 & 250 \\
\hline Wave 2 to 3 & 121 & 88 & 209 & 121 & 89 & 210 \\
\hline Wave 3 to 4 & 109 & 78 & 187 & 110 & 78 & 188 \\
\hline Wave 4 to 5 & 85 & 57 & 142 & 85 & 57 & 142 \\
\hline Pooled & 467 & 321 & 788 & 468 & 322 & 790 \\
\hline
\end{tabular}

Source: Authors' calculation based on Minnesota survey data (provider changes) and administrative data (subsidy status)

Note: Initial subsidy receipt refers to subsidy receipt during the first of the two waves referred to in each row.

Sample characteristics available in the appendix. 
Table 5. Type of care (percentages) (1) before subsidy and once receiving subsidy, children entering subsidy between waves and (2) while receiving subsidy and after subsidy, children exiting subsidy between waves

(1) Children entering subsidy between waves

Once receiving subsidy

\begin{tabular}{lrrrrrr} 
& \multicolumn{3}{c}{ Total } & $\begin{array}{r}\text { N } \\
\text { (children } \\
\text { Before subsidy }\end{array}$ \\
\hline Center & Center & FCC & FFN & Parental & Total \\
FCC & 86.7 & 6.7 & 6.7 & 0.0 & 100.0 & 15 \\
FFN & 33.3 & 66.7 & 0.0 & 0.0 & 100.0 & 3 \\
Parental & 61.5 & 7.7 & 20.5 & 10.3 & 100.0 & 39 \\
\hline Total & 82.4 & 11.8 & 0.0 & 5.9 & 100.0 & 17 \\
\hline
\end{tabular}

(2) Children exiting subsidy between waves

\begin{tabular}{lrrrrrr}
\hline \multicolumn{7}{c}{ After subsidy } \\
While receiving subsidy & Center & FCC & FFN & Parental & Total & $\begin{array}{r}\text { N } \\
\text { (children }\end{array}$ \\
\hline Center & 44.2 & 1.9 & 36.5 & 17.3 & 100.0 & 52 \\
FCC & 10.0 & 50.0 & 10.0 & 30.0 & 100.0 & 10 \\
FFN & 11.1 & 0.0 & 72.2 & 16.7 & 100.0 & 18 \\
Parental & 0.0 & 0.0 & 66.7 & 33.3 & 100.0 & 3 \\
\hline Total & 31.3 & 7.2 & 42.2 & 19.3 & 100.0 & 83 \\
\hline
\end{tabular}

Source: Authors' calculation based on Minnesota survey data (characteristics) and administrative data (subsidy status) 
Table 6. Child fixed effects OLS regression for probability of change in primary provider

\begin{tabular}{|c|c|c|}
\hline & $\begin{array}{l}\text { Provider } \\
\text { change, } \\
\text { including all } \\
\text { initial care } \\
\text { types }\end{array}$ & $\begin{array}{l}\text { Provider } \\
\text { change, } \\
\text { excluding } \\
\text { initial } \\
\text { parental care } \\
\text { only }\end{array}$ \\
\hline \multicolumn{3}{|l|}{ Initial Characteristics } \\
\hline Subsidy receipt & $\begin{array}{l}-0.016 \\
(0.069)\end{array}$ & $\begin{array}{l}-0.046 \\
(0.075)\end{array}$ \\
\hline \multicolumn{3}{|l|}{ Type of care (center omitted) } \\
\hline Family child care & $\begin{array}{l}0.193+ \\
(0.107)\end{array}$ & $\begin{array}{l}0.165 \\
(0.123)\end{array}$ \\
\hline Family/friend/neighbor & $\begin{array}{l}0.207 * * \\
(0.065)\end{array}$ & $\begin{array}{l}0.204 * * \\
(0.069)\end{array}$ \\
\hline Parental only & $\begin{array}{l}0.204^{*} \\
(0.080)\end{array}$ & \\
\hline \multicolumn{3}{|l|}{ Child age (infant omitted) } \\
\hline Toddler & $\begin{array}{l}0.002 \\
(0.069)\end{array}$ & $\begin{array}{l}0.031 \\
(0.077)\end{array}$ \\
\hline Preschooler & $\begin{array}{l}0.041 \\
(0.101)\end{array}$ & $\begin{array}{l}0.034 \\
(0.110)\end{array}$ \\
\hline School age & $\begin{array}{l}-0.048 \\
(0.153)\end{array}$ & $\begin{array}{l}-0.098 \\
(0.173)\end{array}$ \\
\hline Single parent & $\begin{array}{l}-0.071 \\
(0.084)\end{array}$ & $\begin{array}{l}-0.068 \\
(0.092)\end{array}$ \\
\hline Number of other adults & $\begin{array}{l}0.004 \\
(0.042)\end{array}$ & $\begin{array}{l}-0.010 \\
(0.047)\end{array}$ \\
\hline Number of children under six & $\begin{array}{l}0.081 \\
(0.083)\end{array}$ & $\begin{array}{l}0.124 \\
(0.086)\end{array}$ \\
\hline Number of children 6-12 & $\begin{array}{l}0.133+ \\
(0.081)\end{array}$ & $\begin{array}{l}0.151 \\
(0.095)\end{array}$ \\
\hline \multicolumn{3}{|c|}{ Resp. employment (none omitted) } \\
\hline Part time & $\begin{array}{l}0.036 \\
(0.069)\end{array}$ & $\begin{array}{l}0.036 \\
(0.076)\end{array}$ \\
\hline Full time & $\begin{array}{l}-0.081 \\
(0.067)\end{array}$ & $\begin{array}{l}-0.093 \\
(0.070)\end{array}$ \\
\hline Resp. in education/training & $\begin{array}{l}-0.001 \\
(0.059)\end{array}$ & $\begin{array}{l}0.044 \\
(0.060)\end{array}$ \\
\hline Welfare & $\begin{array}{l}0.023 \\
(0.057)\end{array}$ & $\begin{array}{l}-0.005 \\
(0.065)\end{array}$ \\
\hline \multicolumn{3}{|l|}{ Income $(<\$ 15000$ omitted $)$} \\
\hline$\$ 15000-29999$ & $\begin{array}{l}0.017 \\
(0.053)\end{array}$ & $\begin{array}{l}0.028 \\
(0.060)\end{array}$ \\
\hline$\$ 30000+$ & $\begin{array}{l}0.005 \\
(0.080)\end{array}$ & $\begin{array}{l}-0.031 \\
(0.088)\end{array}$ \\
\hline \multicolumn{3}{|l|}{ Changes } \\
\hline Moved & $\begin{array}{l}0.112 * * \\
(0.042)\end{array}$ & $\begin{array}{l}0.131 * * \\
(0.049)\end{array}$ \\
\hline New baby & $\begin{array}{l}0.133 \\
(0.091)\end{array}$ & $\begin{array}{l}0.225^{*} \\
(0.101)\end{array}$ \\
\hline
\end{tabular}

Changes in family/friend care availability (no change 


\begin{tabular}{|c|c|c|}
\hline & $\begin{array}{l}\text { Provider } \\
\text { change, } \\
\text { including all } \\
\text { initial care } \\
\text { types }\end{array}$ & $\begin{array}{l}\text { Provider } \\
\text { change, } \\
\text { excluding } \\
\text { initial } \\
\text { parental care } \\
\text { only }\end{array}$ \\
\hline \multicolumn{3}{|l|}{ omitted) } \\
\hline Gained avail. & $\begin{array}{l}0.165 * * \\
(0.062)\end{array}$ & $\begin{array}{l}0.214 * * \\
(0.069)\end{array}$ \\
\hline Lost avail. & $\begin{array}{l}0.126+ \\
(0.069)\end{array}$ & $\begin{array}{l}0.176 * \\
(0.079)\end{array}$ \\
\hline$\underline{\text { Constant }}$ & $\begin{array}{l}0.180 \\
(0.198)\end{array}$ & $\begin{array}{l}0.128 \\
(0.202)\end{array}$ \\
\hline Model p-value & 0.000 & 0.000 \\
\hline N (observations) & 745 & 628 \\
\hline N (children) & 217 & 196 \\
\hline
\end{tabular}

Source: Authors' calculation based on Minnesota survey data (characteristics, outcome) and administrative data (subsidy status)

Notes: $+p<0.10,{ }^{*} p<0.05, * * p<0.01, * * * p<0.001$

Clustered standard errors in parentheses

In this fixed-effect model, child and family characteristics that are constant over time (child gender, race, parent education, etc.) are controlled for by the child fixed effects.

Sample characteristics available in the appendix. 
Table 7. Number of providers by wave and subsidy status

\begin{tabular}{|c|c|c|c|c|c|}
\hline & \multicolumn{2}{|c|}{ Subsidy recipients } & $\begin{array}{r}\text { Not receiving } \\
\text { subsidy and } \\
\text { in non- } \\
\text { parental care }\end{array}$ & \multirow[b]{2}{*}{$\begin{array}{r}\text { Number of } \\
\text { subsidy } \\
\text { recipients }\end{array}$} & \multirow[b]{2}{*}{$\begin{array}{r}\text { Number not } \\
\text { receiving subsidy } \\
\text { and in non-parental } \\
\text { care }\end{array}$} \\
\hline & $\begin{array}{c}\text { Number of } \\
\text { subsidized } \\
\text { providers }\end{array}$ & $\begin{array}{r}\text { Total number } \\
\text { of providers }\end{array}$ & $\begin{array}{r}\text { Total number } \\
\text { of providers }\end{array}$ & & \\
\hline Wave 1 & 1.08 & 1.73 & 1.84 & 117 & 166 \\
\hline Wave 2 & 1.07 & 1.72 & 1.70 & 96 & 111 \\
\hline Wave 3 & 1.11 & 1.93 & 1.72 & 88 & 102 \\
\hline Wave 4 & 1.07 & 1.66 & 1.89 & 74 & 91 \\
\hline Wave 5 & 1.06 & 1.71 & 1.90 & 49 & 77 \\
\hline Pooled & 1.08 & 1.75 & 1.81 & 424 & 547 \\
\hline
\end{tabular}

Source: Authors' calculation based on Minnesota survey data (number of providers) and administrative data (subsidy status, number of subsidized providers)

Notes: Individuals receiving subsidy in the calendar month but not using non-parental care are excluded.

Sample characteristics available in the appendix. 
Table 8. Care arrangements by subsidy receipt, pooled across waves

\begin{tabular}{|c|c|c|c|c|}
\hline & \multirow[b]{2}{*}{ All children } & \multirow[b]{2}{*}{$\begin{array}{l}\text { Subsidy } \\
\text { recipients }\end{array}$} & \multicolumn{2}{|c|}{ Not receiving subsidy } \\
\hline & & & $\begin{array}{r}\text { All types of } \\
\text { care }\end{array}$ & $\begin{array}{r}\text { Using non- } \\
\text { parental } \\
\text { care }\end{array}$ \\
\hline \multicolumn{5}{|c|}{ Percentage using type of care } \\
\hline Center & 43.2 & 67.7 & 27.7 & 35.3 \\
\hline In home & 34.7 & 29.1 & 38.2 & 48.6 \\
\hline Out of home & 38.7 & 39.6 & 38.2 & 48.6 \\
\hline Any non-parental care & 85.7 & 97.0 & 78.6 & 100.0 \\
\hline Parental care only & 14.3 & 3.0 & 21.4 & 0.0 \\
\hline \multicolumn{5}{|c|}{$\begin{array}{l}\text { Mean number of providers (conditional on } \\
\text { using type of care) }\end{array}$} \\
\hline Center & 1.00 & 1.00 & 1.00 & 1.00 \\
\hline In home & 1.48 & 1.49 & 1.47 & 1.47 \\
\hline Out of home & 1.45 & 1.43 & 1.47 & 1.47 \\
\hline Any non-parental care & 1.78 & 1.75 & 1.81 & 1.81 \\
\hline N (observations) & 1133 & 437 & 696 & 547 \\
\hline
\end{tabular}

Source: Authors' calculation based on Minnesota survey data (type of care, mean providers) and administrative data (subsidy status)

Notes: Sample characteristics available in the appendix. 


\section{Table 9. Child fixed effects OLS regression for number of providers}

\begin{tabular}{|c|c|}
\hline Subsidy receipt & $\begin{array}{l}-0.032 \\
(0.094)\end{array}$ \\
\hline \multicolumn{2}{|l|}{ Child age (infant omitted) } \\
\hline Toddler & $\begin{array}{l}-0.097 \\
(0.106)\end{array}$ \\
\hline Preschooler & $\begin{array}{l}-0.076 \\
(0.151)\end{array}$ \\
\hline School age & $\begin{array}{l}-0.042 \\
(0.228)\end{array}$ \\
\hline Single parent & $\begin{array}{l}-0.005 \\
(0.140)\end{array}$ \\
\hline Number of other adults & $\begin{array}{l}-0.045 \\
(0.086)\end{array}$ \\
\hline Number of children under six & $\begin{array}{l}0.015 \\
(0.119)\end{array}$ \\
\hline Number of children 6-12 & $\begin{array}{l}0.211+ \\
(0.124)\end{array}$ \\
\hline \multicolumn{2}{|l|}{$\begin{array}{l}\text { Resp. employment (none } \\
\text { omitted) }\end{array}$} \\
\hline Part time & $\begin{array}{l}-0.116 \\
(0.111)\end{array}$ \\
\hline Full time & $\begin{array}{l}0.174 \\
(0.118)\end{array}$ \\
\hline Resp. in education/training & $\begin{array}{l}0.093 \\
(0.110)\end{array}$ \\
\hline Welfare & $\begin{array}{l}0.079 \\
(0.095)\end{array}$ \\
\hline \multicolumn{2}{|l|}{ Income $(<\$ 15000$ omitted $)$} \\
\hline$\$ 15000-29999$ & $\begin{array}{l}-0.026 \\
(0.087)\end{array}$ \\
\hline$\$ 30000+$ & $\begin{array}{l}-0.008 \\
(0.134)\end{array}$ \\
\hline Family/friend available & $\begin{array}{l}-0.012 \\
(0.099)\end{array}$ \\
\hline Constant & $\begin{array}{l}1.689 * * * \\
(0.271) \\
\end{array}$ \\
\hline Model p-value & 0.610 \\
\hline N (observations) & 898 \\
\hline $\mathbf{N}$ (children) & 239 \\
\hline
\end{tabular}

Source: Authors' calculation based on Minnesota survey data (characteristics, outcome) and administrative data (subsidy status)

Notes: $+\mathrm{p}<0.10, * \mathrm{p}<0.05, * * \mathrm{p}<0.01, * * * \mathrm{p}<0.001$ 
Clustered standard errors in parentheses

In this fixed-effect model, child and family characteristics that are constant over time (child gender, race, parent education, etc.) are controlled for by the child fixed effects.

Sample characteristics available in the appendix. 
Table 10. Child care quality factor and subsidy receipt by type of care and wave

\begin{tabular}{|c|c|c|c|c|c|c|c|c|c|c|c|c|}
\hline Wave & $\begin{array}{r}\text { No } \\
\text { Subsidy }\end{array}$ & $\begin{array}{l}\text { Center } \\
\text { Subsidy }\end{array}$ & Total & $\begin{array}{r}\text { Fami } \\
\text { No } \\
\text { Subsidy } \\
\end{array}$ & $\begin{array}{l}\text { ily child } \\
\text { Subsidy }\end{array}$ & Total & $\begin{array}{r}\text { Fam } \\
\text { nei } \\
\text { No } \\
\text { Subsidy } \\
\end{array}$ & $\begin{array}{l}\text { ighbor ca } \\
\text { Subsidy }\end{array}$ & Total & $\begin{array}{r}\text { No } \\
\text { Subsidy } \\
\end{array}$ & Subsidy & Total \\
\hline 1 & 0.40 & 0.72 & 0.59 & -0.11 & -0.08 & -0.09 & -0.63 & -0.29 & -0.57 & -0.37 & 0.32 & -0.12 \\
\hline 2 & 0.66 & 0.58 & 0.61 & -0.36 & -0.48 & -0.43 & -0.47 & -0.40 & -0.46 & -0.18 & 0.3 & 0.02 \\
\hline 3 & 0.64 & 0.58 & 0.60 & -0.18 & 0.38 & 0.18 & -0.71 & -0.47 & -0.66 & -0.19 & 0.39 & 0.09 \\
\hline 4 & 0.69 & 0.42 & 0.52 & -0.03 & 0.02 & 0.00 & -0.68 & -0.82 & -0.71 & -0.17 & 0.16 & -0.01 \\
\hline 5 & 0.54 & 0.75 & 0.66 & -0.06 & -0.01 & -0.03 & -0.65 & -0.19 & -0.60 & -0.19 & 0.52 & 0.09 \\
\hline ooled & 0.58 & 0.60 & 0.59 & -0.15 & -0.03 & -0.07 & -0.62 & -0.44 & -0.59 & -0.24 & 0.33 & 0.00 \\
\hline
\end{tabular}

Source: Authors' calculation based on Minnesota survey data (quality factor) and administrative data (subsidy status)

Notes: Sample characteristics available in the appendix. 
Table 11. Child fixed effects OLS regression for quality factor

Model 2:

Type of care

\begin{tabular}{lll} 
& Model 1 & included \\
\hline Subsidy receipt & $0.540^{* * *}$ & $0.148^{*}$ \\
& $(0.087)$ & $(0.072)$
\end{tabular}

Child age (infant omitted)

Toddler

$0.307^{*} \quad 0.185+$

$(0.119) \quad(0.101)$

Preschooler

$0.376^{*}$

0.161

(0.173)

$(0.147)$

School age

0.184

0.186

$(0.239)$

$(0.198)$

Single parent

$-0.002$

$-0.076$

(0.110)

(0.098)

Number of other adults

$-0.067$

$-0.064$

(0.049)

$(0.055)$

Number of children under six

0.149

0.135

(0.126)

(0.115)

Number of children 6-12

0.005

0.080

(0.136)

(0.116)

Resp. employment (none omitted)

Part time

$\begin{array}{ll}-0.046 & -0.019\end{array}$

(0.081) (0.073)

Full time

$-0.005$

$-0.044$

(0.091)

(0.073)

Resp. in education/training

0.120

0.118

$(0.091)$

(0.075)

Welfare

0.111

$0.169 * *$

Income ( $\$ \mathbf{\$ 1 5 0 0 0}$ omitted $)$

(0.073)

(0.064)

\$15000-29999

$\begin{array}{ll}0.096 & 0.059\end{array}$

$\begin{array}{ll}0.070) & (0.061)\end{array}$

$\$ 30000+$

0.108

0.093

(0.118)

(0.092)

$-0.117$

0.045

(0.095)

(0.090)

Type of care (center omitted)

Family child care

$-0.645^{* * *}$

(0.170)

Family/friend/neighbor care

$-1.073 * * *$

(0.111)

Constant

$-0.737 * *$

0.043

$(0.282)$

$(0.257)$

Model p-value

0.000

0.000

N (observations)

703

703

N (children)

$205 \quad 205$


Source: Authors' calculation based on Minnesota survey data (characteristics, outcome) and administrative data (subsidy status)

Notes: $+\mathrm{p}<0.10,{ }^{*} \mathrm{p}<0.05,{ }^{*} \mathrm{p}<<0.01, * * * \mathrm{p}<0.001$

Clustered standard errors in parentheses. Includes only children in non-parental care.

In this fixed-effect model, child and family characteristics that are constant over time (child gender, race, parent education, etc.) are controlled for by the child fixed effects.

Sample characteristics available in the appendix. 


\section{Appendix: Additional Tables on Sample Characteristics for Analysis Samples}

Table 12. Sample of children in non-parental care with quality factor data (Table 1, Table 10)

\begin{tabular}{|c|c|c|c|c|c|}
\hline & Baseline & Wave 2 & Wave 3 & Wave 4 & Wave 5 \\
\hline Subsidy Recipient & 36.7 & 41.3 & 47.2 & 46.5 & 38.5 \\
\hline \multicolumn{6}{|l|}{ Type of care } \\
\hline Center & 34.8 & 44.5 & 53.4 & 52.8 & 49.6 \\
\hline FCC & 11.0 & 7.7 & 8.7 & 6.9 & 10.3 \\
\hline FFN & 54.3 & 47.7 & 37.9 & 40.3 & 40.2 \\
\hline Parental care only & N/A & N/A & N/A & N/A & N/A \\
\hline \multicolumn{6}{|l|}{ Child Sex } \\
\hline Female & 51.9 & 49.7 & 48.4 & 48.6 & 47.0 \\
\hline Male & 48.1 & 50.3 & 51.6 & 51.4 & 53.0 \\
\hline \multicolumn{6}{|l|}{ Child age } \\
\hline Infant & 26.2 & 19.4 & 9.3 & 0.0 & 0.0 \\
\hline Toddler & 31.9 & 25.8 & 24.2 & 26.4 & 17.1 \\
\hline Preschooler & 37.6 & 49.0 & 55.3 & 67.4 & 59.8 \\
\hline School age & 4.3 & 5.8 & 11.2 & 6.2 & 23.1 \\
\hline \multicolumn{6}{|l|}{ Child race } \\
\hline White, non-Hispanic & 28.1 & 29.0 & 32.3 & 28.5 & 29.1 \\
\hline Hispanic & 13.8 & 9.0 & 9.9 & 9.7 & 6.8 \\
\hline Non-White, non-Hispanic & 58.1 & 61.9 & 57.8 & 61.8 & 64.1 \\
\hline Single parent & 68.1 & 64.5 & 61.5 & 59.7 & 69.2 \\
\hline \multicolumn{6}{|l|}{ Resp. Education } \\
\hline Less than high school & 26.2 & 22.6 & 19.9 & 23.6 & 18.8 \\
\hline High school & 34.3 & 31.0 & 34.2 & 29.9 & 29.9 \\
\hline Some college & 36.2 & 40.0 & 39.8 & 40.3 & 46.2 \\
\hline $\mathrm{BA}+$ & 3.3 & 6.5 & 6.2 & 6.2 & 5.1 \\
\hline \multicolumn{6}{|l|}{ Resp. employment } \\
\hline None & 58.6 & 42.2 & 31.7 & 35.4 & 25.6 \\
\hline Part-time & 22.4 & 15.6 & 17.4 & 11.1 & 22.2 \\
\hline Full-time & 19.0 & 42.2 & 50.9 & 53.5 & 52.1 \\
\hline Resp. in education/training & 25.7 & 24.5 & 16.8 & 16.7 & 17.1 \\
\hline \multicolumn{6}{|l|}{ Household income } \\
\hline Under $\$ 15,000$ & 54.3 & 59.4 & 47.8 & 43.8 & 41.0 \\
\hline$\$ 15,000-\$ 29,999$ & 34.3 & 25.2 & 35.4 & 41.0 & 30.8 \\
\hline$\$ 30,000+$ & 11.4 & 15.5 & 16.8 & 15.3 & 28.2 \\
\hline Welfare & 73.3 & 65.2 & 54.0 & 43.1 & 37.6 \\
\hline $\begin{array}{l}\text { Family or friend available to c } \\
\text { child }\end{array}$ & 58.1 & 60.6 & 57.1 & 50.7 & 56.4 \\
\hline Total & 100.0 & 100.0 & 100.0 & 100.0 & 100.0 \\
\hline \multicolumn{6}{|l|}{ Means } \\
\hline Number of other adults & 0.72 & 0.74 & 0.65 & 0.69 & 0.57 \\
\hline Number of children under six & 1.44 & 1.34 & 1.36 & 1.39 & 1.32 \\
\hline Number of children 6-12 & 0.37 & 0.42 & 0.47 & 0.47 & 0.61 \\
\hline $\mathbf{N}$ (observations) & 210 & 155 & 161 & 144 & 117 \\
\hline
\end{tabular}

Source: Authors' calculation based on Minnesota survey data (characteristics, outcome) and administrative data (subsidy status) 
Table 13. Sample of children observed at least two waves (Table 3, Table 4)

\begin{tabular}{|c|c|c|c|c|c|}
\hline & Baseline & Wave 2 & Wave 3 & Wave 4 & Wave 5 \\
\hline Subsidy Recipient & 39.1 & 39.6 & 43.3 & 39.9 & 33.8 \\
\hline \multicolumn{6}{|l|}{ Type of care } \\
\hline Center & 32.0 & 37.6 & 45.5 & 43.1 & 41.5 \\
\hline FCC & 11.3 & 10.8 & 10.0 & 8.5 & 9.2 \\
\hline FFN & 44.1 & 34.4 & 32.1 & 34.0 & 35.2 \\
\hline Parental care only & 12.5 & 17.2 & 12.4 & 14.4 & 14.1 \\
\hline \multicolumn{6}{|l|}{ Child Sex } \\
\hline Female & 50.4 & 50.0 & 49.0 & 49.5 & 48.6 \\
\hline Male & 49.6 & 50.0 & 51.0 & 50.5 & 51.4 \\
\hline \multicolumn{6}{|l|}{ Child age } \\
\hline Infant & 29.3 & 19.2 & 8.6 & 0.0 & 0.0 \\
\hline Toddler & 28.1 & 28.4 & 28.1 & 28.7 & 18.3 \\
\hline Preschooler & 36.7 & 46.8 & 49.5 & 63.3 & 55.6 \\
\hline School age & 5.9 & 5.6 & 13.8 & 8.0 & 26.1 \\
\hline \multicolumn{6}{|l|}{ Child race } \\
\hline White, non-Hispanic & 30.5 & 30.4 & 31.0 & 30.3 & 31.0 \\
\hline Hispanic & 10.9 & 11.2 & 10.0 & 9.6 & 9.2 \\
\hline Non-White, non-Hispanic & 58.6 & 58.4 & 59.0 & 60.1 & 59.9 \\
\hline Single parent & 64.1 & 60.8 & 58.6 & 58.5 & 62.7 \\
\hline \multicolumn{6}{|l|}{ Resp. Education } \\
\hline Less than high school & 23.8 & 23.6 & 23.3 & 22.3 & 21.8 \\
\hline High school & 35.2 & 34.8 & 34.8 & 35.6 & 32.4 \\
\hline Some college & 36.3 & 36.8 & 36.2 & 36.7 & 40.8 \\
\hline $\mathrm{BA}+$ & 4.7 & 4.8 & 5.7 & 5.3 & 4.9 \\
\hline \multicolumn{6}{|l|}{ Resp. employment } \\
\hline None & 56.2 & 45.8 & 35.9 & 36.2 & 31.0 \\
\hline Part-time & 18.8 & 14.1 & 16.3 & 12.8 & 20.4 \\
\hline Full-time & 25.0 & 40.2 & 47.8 & 51.1 & 48.6 \\
\hline Resp. in education/training & 23.4 & 23.6 & 16.2 & 17.6 & 18.3 \\
\hline \multicolumn{6}{|l|}{ Household income } \\
\hline Under $\$ 15,000$ & 51.6 & 57.2 & 49.5 & 46.3 & 37.3 \\
\hline$\$ 15,000-\$ 29,999$ & 33.2 & 28.8 & 34.3 & 39.4 & 31.7 \\
\hline$\$ 30,000+$ & 15.2 & 14.0 & 16.2 & 14.4 & 31.0 \\
\hline Welfare & 68.8 & 61.2 & 53.3 & 42.6 & 36.6 \\
\hline $\begin{array}{l}\text { Family or friend available to care for } \\
\text { child }\end{array}$ & 54.7 & 54.0 & 53.8 & 52.1 & 59.9 \\
\hline Total & 100.0 & 100.0 & 100.0 & 100.0 & 100.0 \\
\hline \multicolumn{6}{|l|}{ Means } \\
\hline Number of other adults & 0.73 & 0.77 & 0.69 & 0.70 & 0.65 \\
\hline Number of children under six & 1.44 & 1.40 & 1.41 & 1.38 & 1.34 \\
\hline Number of children 6-12 & 0.39 & 0.45 & 0.48 & 0.52 & 0.68 \\
\hline $\mathbf{N}$ (observations) & 256 & 250 & 210 & 188 & 142 \\
\hline
\end{tabular}

Notes: Includes baseline characteristics of the $\mathrm{N}=790$ observations included in a pair of waves Source: Authors' calculation based on Minnesota survey data (characteristics, outcome) and administrative data (subsidy status) 
Table 14. Sample of children for provider change model, including all initial care types (Table 6, first column)

\begin{tabular}{|c|c|c|c|c|c|}
\hline & Baseline & Wave 2 & Wave 3 & Wave 4 & Wave 5 \\
\hline Subsidy Recipient & 40.1 & 41.9 & 43.8 & 39.9 & 34.5 \\
\hline \multicolumn{6}{|l|}{ Type of care } \\
\hline Center & 33.2 & 39.5 & 45.2 & 43.7 & 42.4 \\
\hline FCC & 12.4 & 11.2 & 10.1 & 8.7 & 8.6 \\
\hline FFN & 41.9 & 33.0 & 32.2 & 33.9 & 35.3 \\
\hline Parental care only & 12.4 & 16.3 & 12.5 & 13.7 & 13.7 \\
\hline \multicolumn{6}{|l|}{ Child Sex } \\
\hline Female & 49.8 & 49.3 & 48.6 & 49.2 & 48.9 \\
\hline Male & 50.2 & 50.7 & 51.4 & 50.8 & 51.1 \\
\hline \multicolumn{6}{|l|}{ Child age } \\
\hline Infant & 30.0 & 19.1 & 8.7 & 0.0 & 0.0 \\
\hline Toddler & 28.6 & 29.3 & 28.4 & 28.4 & 18.7 \\
\hline Preschooler & 35.5 & 46.0 & 49.0 & 63.4 & 55.4 \\
\hline School age & 6.0 & 5.6 & 13.9 & 8.2 & 25.9 \\
\hline \multicolumn{6}{|l|}{ Child race } \\
\hline White, non-Hispanic & 30.4 & 30.7 & 30.8 & 29.5 & 30.9 \\
\hline Hispanic & 10.1 & 10.2 & 10.1 & 9.8 & 9.4 \\
\hline Non-White, non-Hispanic & 59.4 & 59.1 & 59.1 & 60.7 & 59.7 \\
\hline Single parent & 64.1 & 60.9 & 58.2 & 57.9 & 64.0 \\
\hline \multicolumn{6}{|l|}{ Resp. Education } \\
\hline Less than high school & 23.5 & 23.7 & 23.6 & 21.9 & 21.6 \\
\hline High school & 34.6 & 34.4 & 34.6 & 35.5 & 32.4 \\
\hline Some college & 36.4 & 36.3 & 36.1 & 37.2 & 41.0 \\
\hline $\mathrm{BA}+$ & 5.5 & 5.6 & 5.8 & 5.5 & 5.0 \\
\hline \multicolumn{6}{|l|}{ Resp. employment } \\
\hline None & 53.9 & 45.3 & 35.3 & 35.0 & 30.9 \\
\hline Part-time & 20.3 & 14.5 & 16.4 & 13.1 & 20.1 \\
\hline Full-time & 25.8 & 40.2 & 48.3 & 51.9 & 48.9 \\
\hline Resp. in education/training & 24.4 & 22.3 & 16.3 & 16.9 & 18.7 \\
\hline \multicolumn{6}{|l|}{ Household income } \\
\hline Under $\$ 15,000$ & 50.7 & 57.7 & 50.0 & 46.4 & 37.4 \\
\hline$\$ 15,000-\$ 29,999$ & 33.2 & 27.9 & 33.7 & 38.8 & 31.7 \\
\hline$\$ 30,000+$ & 16.1 & 14.4 & 16.3 & 14.8 & 30.9 \\
\hline Welfare & 67.7 & 59.5 & 53.4 & 42.1 & 36.0 \\
\hline $\begin{array}{l}\text { Family or friend available to care for } \\
\text { child }\end{array}$ & 52.1 & 52.1 & 53.8 & 53.0 & 59.7 \\
\hline Total & 100.0 & 100.0 & 100.0 & 100.0 & 100.0 \\
\hline \multicolumn{6}{|l|}{ Means } \\
\hline Number of other adults & 0.71 & 0.74 & 0.69 & 0.70 & 0.64 \\
\hline Number of children under six & 1.41 & 1.39 & 1.41 & 1.37 & 1.34 \\
\hline Number of children 6-12 & 0.38 & 0.42 & 0.48 & 0.52 & 0.68 \\
\hline $\mathbf{N}$ (observations) & 217 & 215 & 208 & 183 & 139 \\
\hline
\end{tabular}

Notes: Includes baseline characteristics of the $\mathrm{N}=745$ observations included in a pair of waves Source: Authors' calculation based on Minnesota survey data (characteristics, outcome) and administrative data (subsidy status) 
Table 15. Sample of children for provider change model, excluding initial parental care only (Table 6 , second column)

\begin{tabular}{|c|c|c|c|c|c|}
\hline & Baseline & Wave 2 & Wave 3 & Wave 4 & Wave 5 \\
\hline Subsidy Recipient & 42.3 & 46.1 & 49.1 & 41.4 & 38.3 \\
\hline \multicolumn{6}{|l|}{ Type of care } \\
\hline Center & 35.2 & 42.2 & 49.1 & 46.5 & 45.8 \\
\hline FCC & 13.8 & 13.3 & 10.5 & 10.2 & 10.0 \\
\hline FFN & 43.9 & 35.0 & 32.7 & 35.0 & 33.3 \\
\hline Parental care only & 7.1 & 9.4 & 7.6 & 8.3 & 10.8 \\
\hline \multicolumn{6}{|l|}{ Child Sex } \\
\hline Female & 48.5 & 46.7 & 48.5 & 47.8 & 50.8 \\
\hline Male & 51.5 & 53.3 & 51.5 & 52.2 & 49.2 \\
\hline \multicolumn{6}{|l|}{ Child age } \\
\hline Infant & 30.1 & 19.4 & 9.4 & 0.0 & 0.0 \\
\hline Toddler & 29.6 & 28.9 & 26.3 & 27.4 & 20.0 \\
\hline Preschooler & 35.7 & 47.2 & 52.0 & 65.0 & 54.2 \\
\hline School age & 4.6 & 4.4 & 12.3 & 7.6 & 25.8 \\
\hline \multicolumn{6}{|l|}{ Child race } \\
\hline White, non-Hispanic & 31.6 & 31.7 & 32.2 & 32.5 & 30.8 \\
\hline Hispanic & 8.2 & 7.8 & 7.6 & 8.9 & 8.3 \\
\hline Non-White, non-Hispanic & 60.2 & 60.6 & 60.2 & 58.6 & 60.8 \\
\hline Single parent & 66.3 & 65.6 & 63.2 & 61.1 & 65.8 \\
\hline \multicolumn{6}{|l|}{ Resp. Education } \\
\hline Less than high school & 22.4 & 22.2 & 22.8 & 19.7 & 20.8 \\
\hline High school & 33.7 & 33.9 & 31.0 & 35.7 & 31.7 \\
\hline Some college & 37.8 & 38.3 & 39.2 & 38.2 & 41.7 \\
\hline $\mathrm{BA}+$ & 6.1 & 5.6 & 7.0 & 6.4 & 5.8 \\
\hline \multicolumn{6}{|l|}{ Resp. employment } \\
\hline None & 53.1 & 45.3 & 31.2 & 35.0 & 31.7 \\
\hline Part-time & 20.4 & 12.3 & 17.1 & 10.8 & 15.8 \\
\hline Full-time & 26.5 & 42.5 & 51.8 & 54.1 & 52.5 \\
\hline Resp. in education/training & 25.0 & 23.9 & 18.1 & 17.8 & 20.8 \\
\hline \multicolumn{6}{|l|}{ Household income } \\
\hline Under $\$ 15,000$ & 50.0 & 58.9 & 48.5 & 45.2 & 33.3 \\
\hline$\$ 15,000-\$ 29,999$ & 33.7 & 26.1 & 33.3 & 40.1 & 33.3 \\
\hline$\$ 30,000+$ & 16.3 & 15.0 & 18.1 & 14.6 & 33.3 \\
\hline Welfare & 67.3 & 60.0 & 53.8 & 42.0 & 34.2 \\
\hline $\begin{array}{l}\text { Family or friend available to care for } \\
\text { child }\end{array}$ & 52.6 & 54.4 & 52.6 & 51.6 & 59.2 \\
\hline Total & 100.0 & 100.0 & 100.0 & 100.0 & 100.0 \\
\hline \multicolumn{6}{|l|}{ Means } \\
\hline Number of other adults & 0.69 & 0.73 & 0.67 & 0.69 & 0.61 \\
\hline Number of children under six & 1.38 & 1.32 & 1.36 & 1.36 & 1.33 \\
\hline Number of children 6-12 & 0.32 & 0.38 & 0.42 & 0.48 & 0.64 \\
\hline $\mathbf{N}$ (observations) & 196 & 180 & 171 & 157 & 120 \\
\hline
\end{tabular}

Notes: Includes baseline characteristics of the $\mathrm{N}=628$ observations included in a pair of waves Source: Authors' calculation based on Minnesota survey data (characteristics, outcome) and administrative data (subsidy status) 
Table 16. Sample of children in non-parental care (Table 7)

\begin{tabular}{|c|c|c|c|c|c|}
\hline & Baseline & Wave 2 & Wave 3 & Wave 4 & Wave 5 \\
\hline Subsidy Recipient & 41.3 & 46.4 & 46.3 & 44.8 & 38.9 \\
\hline \multicolumn{6}{|l|}{ Type of care } \\
\hline Center & 35.7 & 45.4 & 51.9 & 49.7 & 48.4 \\
\hline FCC & 13.4 & 13.0 & 11.1 & 10.3 & 11.1 \\
\hline FFN & 50.9 & 41.5 & 37.0 & 40.0 & 40.5 \\
\hline Parental care only & N/A & N/A & N/A & N/A & N/A \\
\hline \multicolumn{6}{|l|}{ Child Sex } \\
\hline Female & 49.8 & 50.2 & 49.5 & 49.7 & 48.4 \\
\hline Male & 50.2 & 49.8 & 50.5 & 50.3 & 51.6 \\
\hline \multicolumn{6}{|l|}{ Child age } \\
\hline Infant & 30.0 & 19.3 & 8.9 & 0.0 & 0.0 \\
\hline Toddler & 29.0 & 28.0 & 26.8 & 27.3 & 16.7 \\
\hline Preschooler & 36.7 & 46.9 & 51.6 & 66.7 & 59.5 \\
\hline School age & 4.2 & 5.8 & 12.6 & 6.1 & 23.8 \\
\hline \multicolumn{6}{|l|}{ Child race } \\
\hline White, non-Hispanic & 30.4 & 30.9 & 33.2 & 30.9 & 31.0 \\
\hline Hispanic & 12.0 & 8.7 & 8.4 & 8.5 & 6.3 \\
\hline Non-White, non-Hispanic & 57.6 & 60.4 & 58.4 & 60.6 & 62.7 \\
\hline Single parent & 68.6 & 64.7 & 60.5 & 59.4 & 69.0 \\
\hline \multicolumn{6}{|l|}{ Resp. Education } \\
\hline Less than high school & 24.7 & 22.7 & 21.6 & 22.4 & 19.0 \\
\hline High school & 34.6 & 32.9 & 35.3 & 33.9 & 32.5 \\
\hline Some college & 36.4 & 38.6 & 36.8 & 37.6 & 43.7 \\
\hline $\mathrm{BA}+$ & 4.2 & 5.8 & 6.3 & 6.1 & 4.8 \\
\hline \multicolumn{6}{|l|}{ Resp. employment } \\
\hline None & 55.5 & 41.7 & 34.9 & 34.5 & 26.2 \\
\hline Part-time & 19.4 & 14.6 & 16.4 & 10.3 & 21.4 \\
\hline Full-time & 25.1 & 43.7 & 48.7 & 55.2 & 52.4 \\
\hline Resp. in education/training & 25.4 & 24.2 & 17.9 & 17.0 & 17.5 \\
\hline \multicolumn{6}{|l|}{ Household income } \\
\hline Under $\$ 15,000$ & 54.1 & 58.0 & 47.4 & 43.6 & 39.7 \\
\hline$\$ 15,000-\$ 29,999$ & 34.6 & 26.1 & 35.3 & 40.6 & 31.0 \\
\hline$\$ 30,000+$ & 11.3 & 15.9 & 17.4 & 15.8 & 29.4 \\
\hline Welfare & 71.4 & 62.8 & 52.6 & 41.8 & 37.3 \\
\hline $\begin{array}{l}\text { Family or friend available to care for } \\
\text { child }\end{array}$ & 55.5 & 55.6 & 52.6 & 50.6 & 57.1 \\
\hline Total & 100.0 & 100.0 & 100.0 & 100.0 & 100.0 \\
\hline \multicolumn{6}{|l|}{ Means } \\
\hline Number of other adults & 0.74 & 0.74 & 0.65 & 0.68 & 0.60 \\
\hline Number of children under six & 1.41 & 1.34 & 1.41 & 1.40 & 1.33 \\
\hline Number of children 6-12 & 0.35 & 0.42 & 0.45 & 0.47 & 0.63 \\
\hline $\mathbf{N}$ (observations) & 283 & 207 & 190 & 165 & 126 \\
\hline
\end{tabular}

Source: Authors' calculation based on Minnesota survey data (characteristics, outcome) and administrative data (subsidy status) 
Table 17. Sample of all children (Table 8)

\begin{tabular}{|c|c|c|c|c|c|}
\hline & Baseline & Wave 2 & Wave 3 & Wave 4 & Wave 5 \\
\hline Subsidy Recipient & 37.5 & 39.6 & 42.2 & 38.8 & 33.6 \\
\hline \multicolumn{6}{|l|}{ Type of care } \\
\hline Center & 31.3 & 37.6 & 45.2 & 41.8 & 41.8 \\
\hline $\mathrm{FCC}$ & 11.8 & 10.8 & 9.7 & 8.7 & 9.6 \\
\hline FFN & 44.6 & 34.4 & 32.3 & 33.7 & 34.9 \\
\hline Parental care only & 12.4 & 17.2 & 12.9 & 15.8 & 13.7 \\
\hline \multicolumn{6}{|l|}{ Child Sex } \\
\hline Female & 51.1 & 50.0 & 50.5 & 50.0 & 47.9 \\
\hline Male & 48.9 & 50.0 & 49.5 & 50.0 & 52.1 \\
\hline \multicolumn{6}{|l|}{ Child age } \\
\hline Infant & 30.7 & 19.2 & 8.3 & 0.0 & 0.0 \\
\hline Toddler & 27.9 & 28.4 & 28.0 & 27.6 & 17.8 \\
\hline Preschooler & 36.2 & 46.8 & 50.0 & 62.8 & 56.8 \\
\hline School age & 5.3 & 5.6 & 13.8 & 9.7 & 25.3 \\
\hline \multicolumn{6}{|l|}{ Child race } \\
\hline White, non-Hispanic & 29.1 & 30.4 & 30.7 & 29.6 & 31.5 \\
\hline Hispanic & 13.0 & 11.2 & 9.6 & 9.7 & 8.9 \\
\hline Non-White, non-Hispanic & 57.9 & 58.4 & 59.6 & 60.7 & 59.6 \\
\hline Single parent & 63.8 & 60.8 & 57.3 & 58.7 & 62.3 \\
\hline \multicolumn{6}{|l|}{ Resp. Education } \\
\hline Less than high school & 25.7 & 23.6 & 23.9 & 23.0 & 22.6 \\
\hline High school & 34.1 & 34.8 & 35.3 & 34.7 & 31.5 \\
\hline Some college & 35.9 & 36.8 & 35.3 & 37.2 & 41.1 \\
\hline $\mathrm{BA}+$ & 4.3 & 4.8 & 5.5 & 5.1 & 4.8 \\
\hline \multicolumn{6}{|l|}{ Resp. employment } \\
\hline None & 57.9 & 45.8 & 36.9 & 37.8 & 30.8 \\
\hline Part-time & 18.0 & 14.1 & 15.7 & 12.8 & 20.5 \\
\hline Full-time & 24.1 & 40.2 & 47.5 & 49.5 & 48.6 \\
\hline Resp. in education/training & 24.1 & 23.6 & 16.1 & 17.3 & 17.8 \\
\hline \multicolumn{6}{|l|}{ Household income } \\
\hline Under $\$ 15,000$ & 53.3 & 57.2 & 50.0 & 46.4 & 38.4 \\
\hline$\$ 15,000-\$ 29,999$ & 34.4 & 28.8 & 33.9 & 38.8 & 30.8 \\
\hline$\$ 30,000+$ & 12.4 & 14.0 & 16.1 & 14.8 & 30.8 \\
\hline Welfare & 71.2 & 61.2 & 53.7 & 42.9 & 37.0 \\
\hline $\begin{array}{l}\text { Family or friend available to care for } \\
\text { child }\end{array}$ & 53.9 & 54.0 & 54.6 & 52.1 & 58.2 \\
\hline Total & 100.0 & 100.0 & 100.0 & 100.0 & 100.0 \\
\hline \multicolumn{6}{|l|}{ Means } \\
\hline Number of other adults & 0.75 & 0.77 & 0.69 & 0.69 & 0.64 \\
\hline Number of children under six & 1.46 & 1.40 & 1.42 & 1.39 & 1.33 \\
\hline Number of children 6-12 & 0.38 & 0.45 & 0.47 & 0.53 & 0.68 \\
\hline $\mathbf{N}$ (observations) & 323 & 250 & 218 & 196 & 146 \\
\hline
\end{tabular}

Source: Authors' calculation based on Minnesota survey data (characteristics, outcome) and administrative data (subsidy status) 
Table 18. Sample of children for number of providers model (Table 9)

\begin{tabular}{|c|c|c|c|c|c|}
\hline & Baseline & Wave 2 & Wave 3 & Wave 4 & Wave 5 \\
\hline Subsidy Recipient & 43.2 & 47.3 & 46.3 & 44.8 & 39.5 \\
\hline \multicolumn{6}{|l|}{ Type of care } \\
\hline Center & 35.9 & 45.8 & 52.4 & 49.7 & 48.4 \\
\hline FCC & 13.2 & 13.3 & 10.7 & 9.8 & 11.3 \\
\hline FFN & 50.9 & 40.9 & 36.9 & 40.5 & 40.3 \\
\hline Parental care only & N/A & N/A & N/A & N/A & N/A \\
\hline \multicolumn{6}{|l|}{ Child Sex } \\
\hline Female & 48.6 & 49.8 & 49.5 & 49.1 & 47.6 \\
\hline Male & 51.4 & 50.2 & 50.5 & 50.9 & 52.4 \\
\hline \multicolumn{6}{|l|}{ Child age } \\
\hline Infant & 29.1 & 19.7 & 9.0 & 0.0 & 0.0 \\
\hline Toddler & 29.5 & 28.1 & 26.6 & 27.0 & 16.9 \\
\hline Preschooler & 37.3 & 46.3 & 52.1 & 66.9 & 58.9 \\
\hline School age & 4.1 & 5.9 & 12.2 & 6.1 & 24.2 \\
\hline \multicolumn{6}{|l|}{ Child race } \\
\hline White, non-Hispanic & 30.9 & 30.5 & 33.0 & 30.7 & 31.5 \\
\hline Hispanic & 8.6 & 8.9 & 8.5 & 8.6 & 6.5 \\
\hline Non-White, non-Hispanic & 60.5 & 60.6 & 58.5 & 60.7 & 62.1 \\
\hline Single parent & 69.1 & 65.5 & 60.1 & 59.5 & 70.2 \\
\hline \multicolumn{6}{|l|}{ Resp. Education } \\
\hline Less than high school & 23.6 & 22.7 & 21.3 & 22.7 & 19.4 \\
\hline High school & 35.0 & 33.0 & 35.6 & 33.1 & 32.3 \\
\hline Some college & 36.8 & 38.4 & 36.7 & 38.0 & 43.5 \\
\hline $\mathrm{BA}+$ & 4.5 & 5.9 & 6.4 & 6.1 & 4.8 \\
\hline \multicolumn{6}{|l|}{ Resp. employment } \\
\hline None & 54.1 & 41.9 & 34.6 & 34.4 & 26.6 \\
\hline Part-time & 19.5 & 13.8 & 16.5 & 10.4 & 21.0 \\
\hline Full-time & 26.4 & 44.3 & 48.9 & 55.2 & 52.4 \\
\hline Resp. in education/training & 25.5 & 24.6 & 17.6 & 16.6 & 17.7 \\
\hline \multicolumn{6}{|l|}{ Household income } \\
\hline Under $\$ 15,000$ & 52.7 & 58.1 & 47.3 & 43.6 & 39.5 \\
\hline$\$ 15,000-\$ 29,999$ & 34.1 & 26.6 & 35.1 & 41.1 & 31.5 \\
\hline$\$ 30,000+$ & 13.2 & 15.3 & 17.6 & 15.3 & 29.0 \\
\hline Welfare & 68.2 & 62.6 & 52.7 & 41.7 & 37.1 \\
\hline $\begin{array}{l}\text { Family or friend available to care for } \\
\text { child }\end{array}$ & 56.4 & 55.2 & 52.7 & 50.9 & 56.5 \\
\hline Total & 100.0 & 100.0 & 100.0 & 100.0 & 100.0 \\
\hline \multicolumn{6}{|l|}{ Means } \\
\hline Number of other adults & 0.70 & 0.73 & 0.65 & 0.69 & 0.59 \\
\hline Number of children under six & 1.40 & 1.35 & 1.40 & 1.40 & 1.31 \\
\hline Number of children 6-12 & 0.33 & 0.41 & 0.44 & 0.47 & 0.63 \\
\hline $\mathbf{N}$ (observations) & 220 & 203 & 188 & 163 & 124 \\
\hline
\end{tabular}

Source: Authors' calculation based on Minnesota survey data (characteristics, outcome) and administrative data (subsidy status) 
Table 19. Sample of children for quality of care model (Table 11)

\begin{tabular}{|c|c|c|c|c|c|}
\hline & Baseline & Wave 2 & Wave 3 & Wave 4 & Wave 5 \\
\hline Subsidy Recipient & 38.3 & 43.2 & 47.5 & 46.0 & 39.4 \\
\hline \multicolumn{6}{|l|}{ Type of care } \\
\hline Center & 36.2 & 45.3 & 53.2 & 51.8 & 50.5 \\
\hline FCC & 10.7 & 8.1 & 8.9 & 7.2 & 9.2 \\
\hline FFN & 53.0 & 46.6 & 38.0 & 41.0 & 40.4 \\
\hline Parental care only & N/A & N/A & N/A & N/A & N/A \\
\hline \multicolumn{6}{|l|}{ Child Sex } \\
\hline Female & 49.7 & 49.3 & 48.1 & 48.2 & 46.8 \\
\hline Male & 50.3 & 50.7 & 51.9 & 51.8 & 53.2 \\
\hline \multicolumn{6}{|l|}{ Child age } \\
\hline Infant & 22.8 & 19.6 & 9.5 & 0.0 & 0.0 \\
\hline Toddler & 32.9 & 25.7 & 24.1 & 26.6 & 18.3 \\
\hline Preschooler & 39.6 & 49.3 & 55.7 & 68.3 & 56.9 \\
\hline School age & 4.7 & 5.4 & 10.8 & 5.0 & 24.8 \\
\hline \multicolumn{6}{|l|}{ Child race } \\
\hline White, non-Hispanic & 26.8 & 27.7 & 32.3 & 29.5 & 28.4 \\
\hline Hispanic & 8.7 & 9.5 & 10.1 & 9.4 & 7.3 \\
\hline Non-White, non-Hispanic & 64.4 & 62.8 & 57.6 & 61.2 & 64.2 \\
\hline Single parent & 70.5 & 66.2 & 62.7 & 59.7 & 70.6 \\
\hline \multicolumn{6}{|l|}{ Resp. Education } \\
\hline Less than high school & 22.8 & 22.3 & 20.3 & 23.7 & 19.3 \\
\hline High school & 34.9 & 31.1 & 33.5 & 28.8 & 27.5 \\
\hline Some college & 37.6 & 39.9 & 40.5 & 41.0 & 47.7 \\
\hline $\mathrm{BA}+$ & 4.7 & 6.8 & 5.7 & 6.5 & 5.5 \\
\hline \multicolumn{6}{|l|}{ Resp. employment } \\
\hline None & 57.7 & 41.9 & 31.6 & 35.3 & 25.7 \\
\hline Part-time & 22.8 & 14.9 & 17.7 & 10.8 & 22.0 \\
\hline Full-time & 19.5 & 43.2 & 50.6 & 54.0 & 52.3 \\
\hline Resp. in education/training & 27.5 & 25.0 & 17.1 & 15.8 & 16.5 \\
\hline \multicolumn{6}{|l|}{ Household income } \\
\hline Under $\$ 15,000$ & 53.7 & 60.1 & 47.5 & 43.9 & 40.4 \\
\hline$\$ 15,000-\$ 29,999$ & 32.9 & 25.7 & 36.1 & 41.0 & 32.1 \\
\hline$\$ 30,000+$ & 13.4 & 14.2 & 16.5 & 15.1 & 27.5 \\
\hline Welfare & 71.1 & 64.9 & 53.8 & 42.4 & 36.7 \\
\hline $\begin{array}{l}\text { Family or friend available to care for } \\
\text { child }\end{array}$ & 59.7 & 60.8 & 57.0 & 51.1 & 56.9 \\
\hline Total & 100.0 & 100.0 & 100.0 & 100.0 & 100.0 \\
\hline \multicolumn{6}{|l|}{ Means } \\
\hline Number of other adults & 0.62 & 0.72 & 0.65 & 0.69 & 0.57 \\
\hline Number of children under six & 1.41 & 1.32 & 1.36 & 1.40 & 1.30 \\
\hline Number of children 6-12 & 0.33 & 0.41 & 0.45 & 0.46 & 0.61 \\
\hline $\mathbf{N}$ (observations) & 149 & 148 & 158 & 139 & 109 \\
\hline
\end{tabular}

Source: Authors' calculation based on Minnesota survey data (characteristics, outcome) and administrative data (subsidy status) 